\title{
Benthic diatom community dynamics in Mediterranean intermittent streams: Effects of water availability and their potential as indicators of dry-phase ecological status
}

\author{
Maria Helena Novais ${ }^{\mathrm{a}, \mathrm{b}, *}$, Eduardo A. Morales ${ }^{\mathrm{a}, \mathrm{c}}$, Alexandra Marchã Penha ${ }^{\mathrm{a}, \mathrm{c}}$, Miguel Potes ${ }^{\mathrm{a}}$, Agnès Bouchez ${ }^{\mathrm{e}}$, \\ Amélie Barthès ${ }^{\mathrm{f}}$, Maria João Costa ${ }^{\mathrm{a}, \mathrm{d}}$, Rui Salgado ${ }^{\mathrm{a}, \mathrm{d}}$, Jorge Santos ${ }^{\mathrm{g}, \mathrm{h}}$, Manuela Morais ${ }^{\mathrm{a}, \mathrm{c}}$ \\ a Institute of Earth Sciences - ICT, University of Évora, Rua Romão Ramalho n. 59, 7000-671 Évora, Portugal \\ ${ }^{\mathrm{b}}$ Renewable Energies Chair, University of Évora, Casa Cordovil, Rua D. Augusto Eduardo Nunes n7, Évora, 7000-651, Portugal \\ c Water Laboratory, University of Évora, P.I.T.E. Rua da Barba Rala No. 1, 7005-345 Évora, Portugal \\ d Department of Physics, ECT, University of Évora, Rua Romão Ramalho $n^{\circ} 59,7000-671$ Évora, Portugal \\ e INRAE, UMR CARRTEL, Thonon, France \\ ${ }^{\mathrm{f}}$ EUROFINS Hydrobiologie France, Vergèze, France \\ ${ }^{g}$ Department of Mathematics, ECT, University of Évora, Rua Romão Ramalho $n^{\circ}$ 59, 7000-671 Évora, Portugal

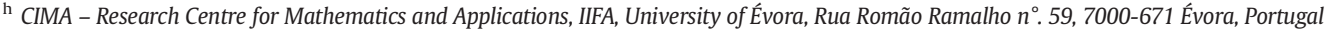

\section{H I G H L I G H T S}

- changes in water physico-chemistry is highly controlled by flow intermittency and subsequent disruption of longitudinal connectivity;

- diatom assemblages reflect the aquatic regimes, aquatic states and sampling habitat;

- SPI reflects the sampling season and mesohabitat;

- no differences between aquatic regimes, aquatic states, sampling seasons and mesohabitats were detected for species richness;

- benthic diatom assemblages in dry biofilm can be used as an indicator of ecological status during the dry-phase.

\section{G R A P H I C A L A B S T RACT}

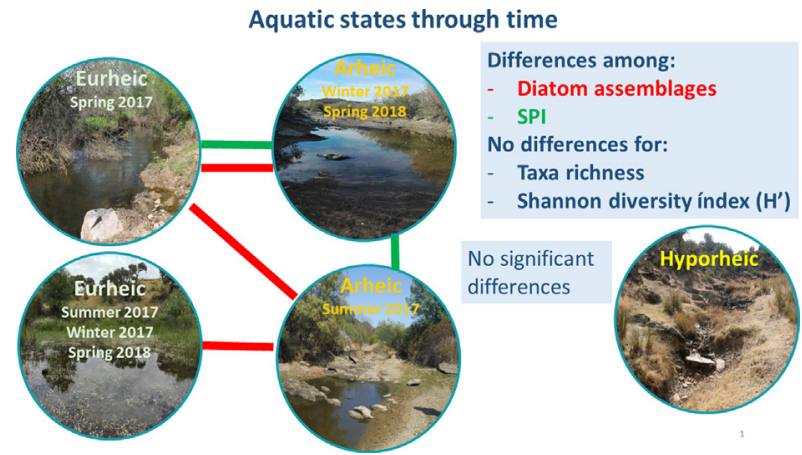

\section{A B S T R A C T}

The study of intermittent rivers is a critical and timely issue due to their worldwide increase, triggered by several causes including climate change. The need to understand the response of intermittent river biota to water intermittency led us to conduct this study using benthic diatoms collected in southern Portugal. Benthic diatoms were explored in terms of assemblages, diversity indices, the Specific Pollution Sensitivity (SPI) Index, functional metrics (i.e. ecological guilds and life-forms) and conservation status. We verified that changes in water physicochemical characteristics were highly controlled by flow intermittency, which in turn is directly linked to meteorological variables (air temperature and precipitation). Changes in diatom assemblages reflect the aquatic regime of sites, changes in aquatic states through time and mesohabitats (dry biofilm, samples collected in pools or under flowing conditions). Species richness, on the other hand, did not reflect these differences, whilst Shannon diversity and Pielou's Evenness indices only reflected mesohabitat differences. The SPI distinguished sampling periods, and mesohabitats. The relative abundance of ecological guilds changed with aquatic states, with the

\footnotetext{
* Corresponding author at: Institute of Earth Sciences - ICT, University of Évora, Rua Romão Ramalho n ${ }^{\circ}$ 59, 7000-671 Évora, Portugal.

E-mail address: hnovais@uevora.pt (M.H. Novais).
} 
Ecological guilds

Ecological status assessment

WFD typology low-profile guild dominating in eurheic and arheic conditions (except during Summer), being replaced by motile taxa in summer arheic conditions, reflecting increases in nutrient and siltation. The hypothesis that benthic diatom assemblages in dry biofilm can be used as an indicator of ecological status during the dry-phase was validated, since no differences between the Ecological Quality Ratio determined in dry biofilm collected in Summer 2017 and the previous Spring 2017 in flowing water. A method is proposed for diatom sampling in dry biofilm, contributing to an integrated ecological status evaluation, which considers the dry-phase and enhances the reach of biomonitoring programs.

(c) 2020 Elsevier B.V. All rights reserved.

\section{Introduction}

Rivers that periodically cease to flow (intermittent rivers) presently comprise a substantial proportion of the total number, length and discharge of the world's rivers (Tooth, 2000). Estimates on the global occurrence of this phenomenon suggest that more than a half of the channels comprised in river networks periodically cease to flow or dry, reaching $80 \%$ of the total watercourses in some regions (Datry et al., 2016), but especially in Southern Europe (Tockner et al., 2009). The study of intermittent rivers is a critical and timely issue, since their number and extension could rapidly increase in regions currently under climate drying trends. Such is the case of the Mediterranean region (IPCC, 2018), already identified as one of the "hot spots" for potential changes in water availability (Giorgi and Lionello, 2008). In fact, climate change can drastically impact natural intermittent rivers, given that changes in air temperature and precipitation patterns can affect water temperature and the duration of the wet and dry phases. Resulting shifts may cause important biodiversity losses in the upcoming decades due to the uncoupling of water temperature and aquatic regimes with the thermal tolerance and flow requirements of organisms (Chiu et al., 2017). This could be particularly dramatic in Mediterranean intermittent rivers, since they support a highly rich biota (Acuña et al., 2014). Thus, there is a compelling need to understand the way the biota inhabiting intermittent rivers responds to water intermittency and to the longitudinal, lateral and vertical contraction/expansion events of the mass of water, up to its greatest contraction, when the entire riverbed is dry (Tockner et al., 2000).

Despite its extensive use in permanent rivers and inclusion as preferred indicators in Water Framework Directive (WFD, Directive 2000/ $60 / \mathrm{EC}$ ) protocols, phytobenthos in intermittent rivers has been generally overlooked and only few studies are available (e.g. Boix et al., 2010; Delgado et al., 2012; Novais et al., 2014; B-Béres et al., 2019). The community structure of benthic diatoms is conditioned by physicochemical parameters as dissolved oxygen, light, temperature, $\mathrm{pH}$ and salinization, which in turn may experience strong fluctuations in intermittent rivers (Gómez et al., 2017). The specific conditions of intermittent rivers, with considerable water level fluctuations, and consequent changes in temperature and light intensity constitute a harsh environment, and there is little information available about the resistance mechanisms of phytobenthos to these conditions. Sabater et al. (2017) compiled some responses of cyanobacteria and algae, that include specific growth forms, cellular structures or genetic adaptations. Namely, mucilage-forming species form stalks or tubes that host the cells in a protective filament, whilst other species, that are not able to resist drying, can migrate to deeper sediments. Souffreau et al. (2013) also suggested that there is a tolerance of terrestrial diatoms resting cells to desiccation. The intermittency effects in the community structure, diatom growth forms and ecological guilds, algal biomass and algal recolonization patterns are still poorly studied (Robson et al., 2008; Barthés et al., 2015; Falasco et al., 2016a; Piano et al., 2017a, 2017b). Recently, B-Béres et al. (2019) showed that the functional richness was significantly lower in intermittent than in permanent streams, highlighting the potential ecological impact of intermittency. There is a notorious lack of information about diatom ecological preferences (Novais et al., 2014), and the research on the use of diatoms as indicators of ecological status in Mediterranean temporary streams, diatom metrics and indices has not considered low-flow and dry-phase periods (e.g. Delgado et al., 2012).

For a long time, benthic diatoms have been considered good ecological indicators, being currently included in the Water Framework Directive (WFD, Directive, 2000/60/EC) as proxies for biomonitoring the ecological status of rivers. However, only the biota present during the flowing phase is currently considered, leaving out the dry phase and giving an incomplete idea of the habitat quality in these ecosystems (Stubbington et al., 2019). Therefore, additions to current methods for ecological status assessment should be implemented, as highlighted by Stubbington et al. (2018). This would result in the improvement of management practices throughout the year, considering the aquatic regimes and states of the rivers.

The preliminary results presented by Stubbington et al. (2019), constitute a basis for the use of diatoms as indicators during the dry phase, and a possible tool for the conservation and management of intermittent rivers. Thus, gathering additional data to demonstrate the adequacy of this group of organisms as indicators of ecological conditions in a situation of an ever-increasing number of intermittent rivers, is of high value.

Herein, we focused our attention on the role of benthic diatoms as potential indicators in southern Portugal, where intermittent rivers represent $>70 \%$ of all watercourses (Agência Portuguesa do Ambiente, I.P.) A.R.H. Alentejo, unpublished data). Our aim was to explore: i) the meteorological conditions of the area, in order to correlate them with the aquatic states of streams; ii) whether benthic diatom composition respond to flow intermittency, and iii) whether diversity indices, Specific Pollution Sensitivity (SPI) Index, functional metrics (i.e. ecological guilds and life-forms) and conservation status could represent valid metrics for the classification of the ecological status of these rivers. In particular, we hypothesised that: 1 ) benthic diatoms in intermittent rivers reflect variations in aquatic regimes, sampling periods, aquatic states through time, and mesohabitats (dry biofilm, samples collected in pools or under flowing conditions); and 2) benthic diatoms in dry biofilm can be used as indicators of ecological status during the dry-phase.

\section{Methods}

\subsection{Study area}

A total of 18 sites located in different streams (1 site per stream) in southern Portugal were sampled for one year (once in Spring, late Summer and Winter 2017, and Spring 2018). The sampling sites are plotted in Figs. 1 and 2 and belong to three hydrographic regions: Guadiana (12 sites), Sado and Mira ( 5 sites) and Ribeiras do Algarve ( 1 site). The selected sites are part of the WFD monitoring network and belong to the following WFD river types: Mountain Rivers in the South (2 sites), Tejo and Sado Sedimentary Deposits (1 site), Small Drainage Basin $\leq 100 \mathrm{~km}^{2}$ (11 sites) and Medium-large Rivers in the South, with drainage basin $>100 \mathrm{~km}^{2}$ ( 4 sites), as can be seen in Table S1.

During the study, field observations allowed the classification of the sites in terms of aquatic regimes. The latter are defined by Gallart et al. (2012) as reflecting the site-specific long-term global variability of the hydrological conditions: Permanent, Intermittent-pools and 

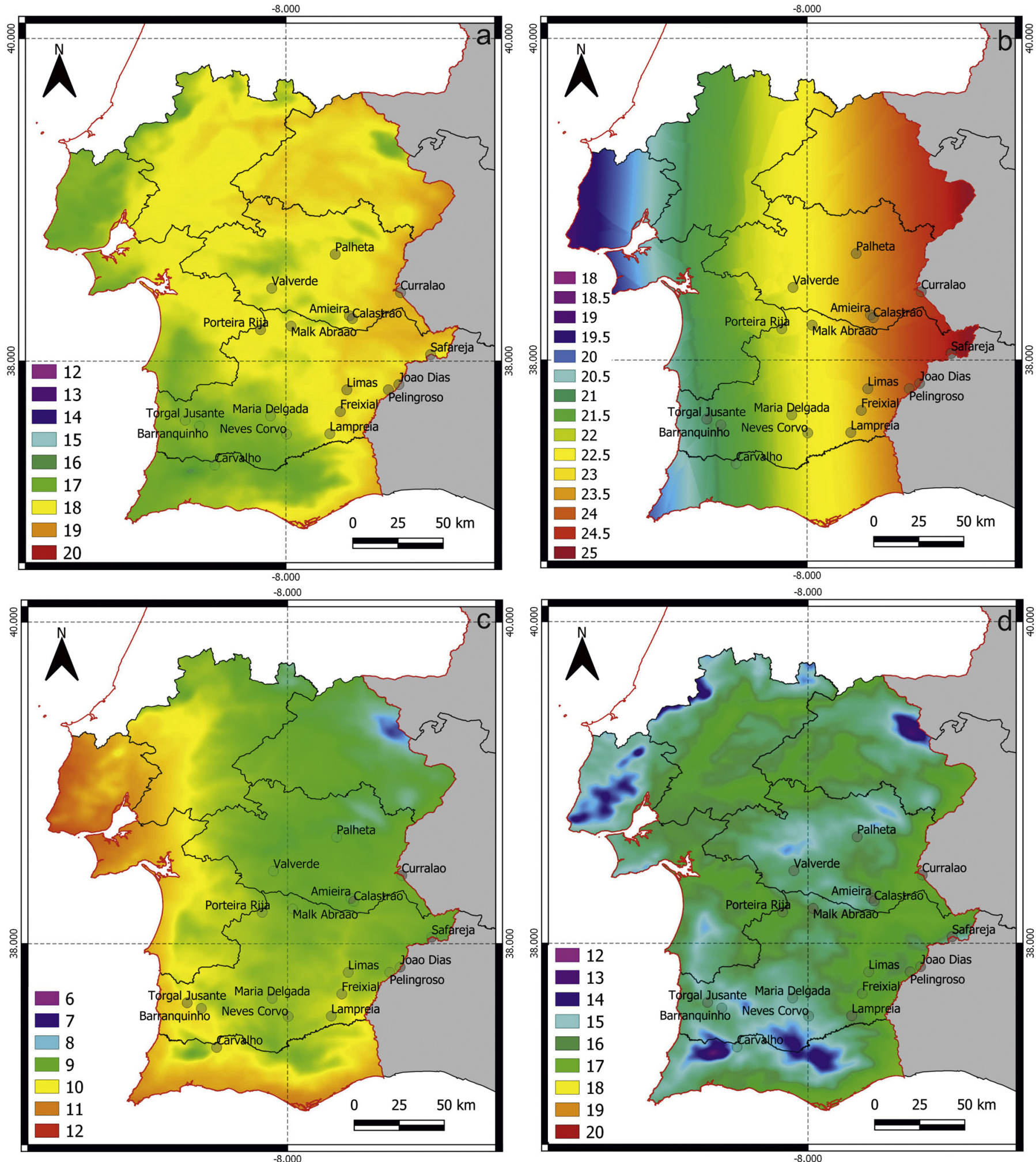

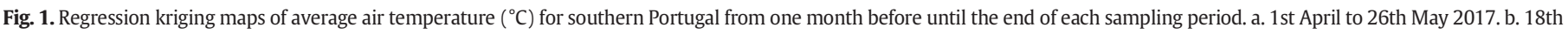
August to 11th October 2017. c. 15th December 2017 to 19th February 2018. d. 9th April to 14th June 2018.

Intermittent-dry. Two sites presented water in the entire channel throughout the study (eurheic conditions), thus being classified as Permanent. Ten sites presented one or two small isolated pools at the end of the Summer 2017, and were classified as Intermittent-pools. The remaining six sites dried out completely at the end of the Summer, and can be classified as Intermittent-dry (Table S1).

All sites are in a region with Mediterranean climate (Csa, according to the Köppen climate classification), with high inter-annual variability, 

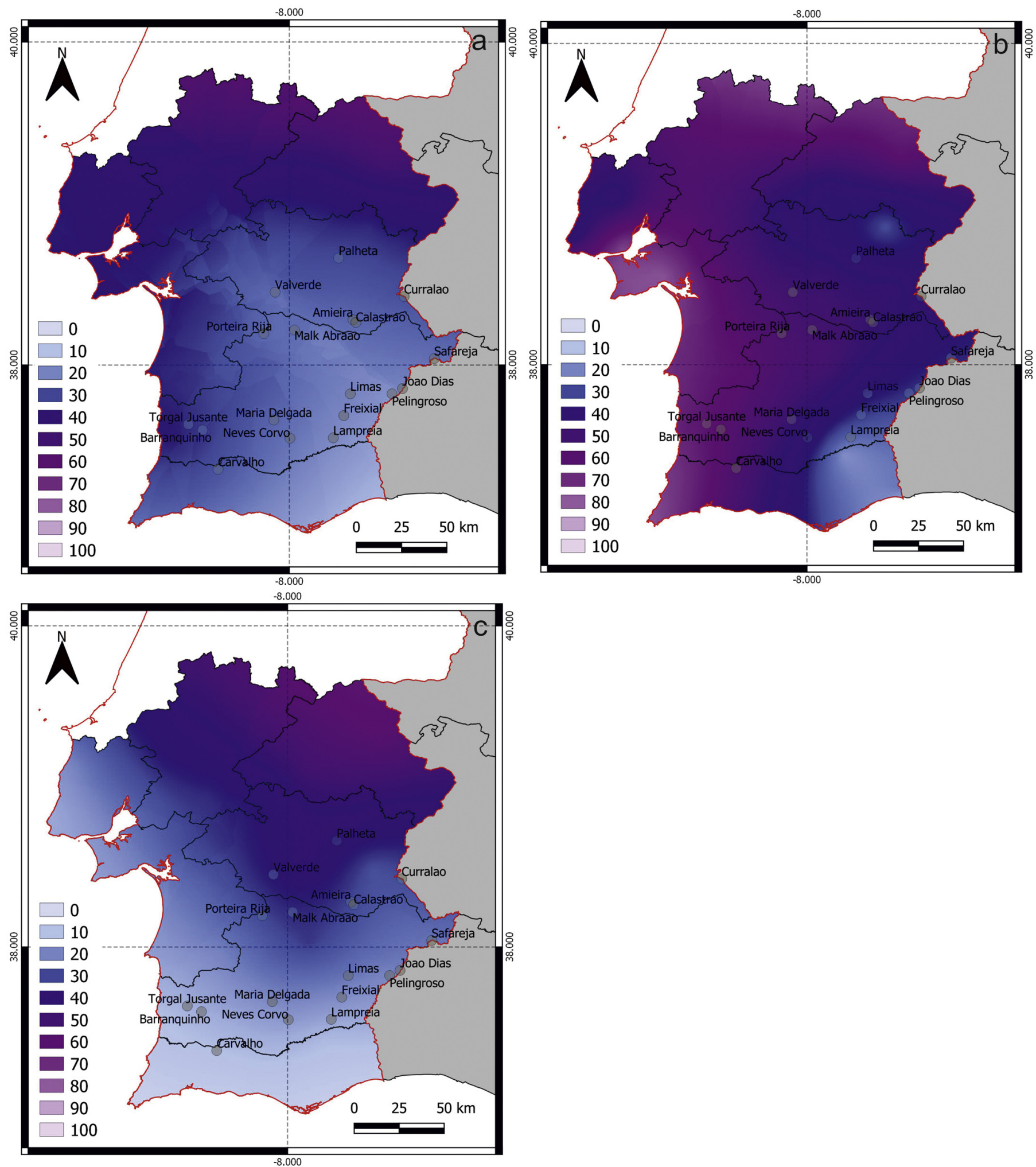

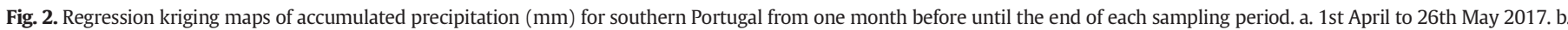
15th December 2017 to 19th February 2018. c. 9th April to 14th June 2018.

and characterized by dry and hot summers, with high solar radiation and potential evapotranspiration and colder, relatively harsh winters (see, for example, Potes et al., 2017).

All sites (except for Carvalho and Barranquinho, Table S1) are in lowlands, in mostly asymmetrical, shallow-V or deep V-shaped valleys; with no distinct flat valley bottom and absence of natural terraces. To minimize the influence of other variables rather than intermittence, sites were selected to be the less modified and anthropogenically influenced as possible, therefore, the effect of nutrients and organic inputs are negligible. The channels are not modified, deepened nor choked with vegetation, they lack dams and weirs, and most of the banks are not modified. Regarding the presence of nuisance species in the 
margins, Arundo donax L. was present in Porteira Rija, Malk Abraão, Barranco do Pelingroso and Lampreia, and Eucalyptus spp. were present in Lampreia, Neves Corvo and Maria Delgada. However, alders were also identified in some of the selected sites, such as Carvalho and Torgal Jusante.

A thorough hydromorphological characterization of the sampling sites was carried out during the first sampling campaign in Spring 2017, following the River Habitat Survey Methodology (Environmental Agency, 2003) and comprising the characterization of a $500 \mathrm{~m}$ stretch of the stream (usually upstream of the sampling site) This included information such as the type of substrate and vegetation present in the channel, flow types, land-use within 5 and $50 \mathrm{~m}$ of the banktops (left and right), vegetation structure in banktops and bankfaces, bank profiles, height of banktop, and other dimensions such as the height above the water surface, channel (bankfull and water) width and depth. Additionally, information about the presence of special features, nuisance species and alders were recorded (Supplementary Material in Tables S2 and S3).

\subsection{Meteorological characterization}

Meteorological data of air temperature and precipitation averaged over 10 -min periods were obtained from 40 meteorological stations operated by the Portuguese Institute for Sea and Atmosphere (IPMA), evenly distributed in the region (Figs. 1 and 2). Data were subsequently averaged over periods of one month ending at the completion of each sampling period. The set of monthly averaged temperature and accumulated precipitation data, corresponding to the 40 stations, were successively spatially interpolated to obtain maps of these meteorological variables. The spatial interpolation of the meteorological data was done following the recommendations of the COST Action 719 Final Report (2008).

The air temperature was interpolated using multivariate linear regression combined with kriging of the residuals. The altitude and distance to the sea were considered as the explanatory variables of the regression model and the residuals obtained at each station were sequentially interpolated using the ordinary kriging method. The interpolated monthly mean air temperature maps result from the sum of the value predicted by the multivariate regression model with the residual value at the same location.

Unlike temperature, precipitation is not spatially and temporally continuous, and its spatial interpolation must account for both occurrence and amount, therefore it constitutes a more intricate problem. The accumulated precipitation was interpolated using ordinary kriging, since, according to COST Action 719 Final Report (2008), this method presents the best performance for a monthly time scale as the one considered here. Both spatial interpolation methods were applied using the open source geographical information system (GIS) software QGIS (version 3.4).

Considering the maps presented in Figs. 1 and 2, three meteorological stations were selected to represent three distinct areas (AljezurSouthwest, Beja-Centre-South and Évora-Centre of the study area) to plot the daily average air temperature and monthly accumulated precipitation during the entire study (Fig. 3).

\subsection{Biological and environmental characterization}

\subsubsection{Environmental parameters}

Sampling was carried out for one year starting in Spring 2017 and including the following aquatic states: eurheic, arheic, hyporheic and edaphic. No sampling was carried out under hyperrheic conditions, since floods cause scouring of the aquatic biota.

The aquatic states, as defined in Gallart et al. (2012), depend on the hydrological conditions and represent the sets of aquatic mesohabitats developing in a reach at a certain time, ranging from hyperrheic to hyporheic and even edaphic. The hyperrheic condition is characterized by high water (flooding), which originates the movement of stream bed alluvium and causes the drift of most of the aquatic fauna in the reach. The eurheic condition has sufficient water discharge to allow the presence of all aquatic habitats in the reach (often comprising abundant riffles), and optimum hydraulic connectivity between habitats. The oligorheic state, in turn has low water discharge, but sufficient to connect most pools in the reach through water rivulets. The arheic type is characterized by a null or close to zero surface discharge, but some pools are still present in the stream bed. The hyporheic type has no surface water in the stream bed in most of the reach, although the alluvium may have sufficient moisture to support hyporheic life. Finally, during the edaphic condition, the stream bed is completely devoid of surface water in the reach and the alluvium is dry, impeding active hyporheic life.

Prior to sampling, a brief characterization of the stretch (in approximately $50 \mathrm{~m}$ along the reach) was carried out, including width of the stream (bank to bank), channel depth and width, water flow, transparency of the water, shading (\%) and the presence and percentage of macrophytes. During arheic conditions, the percentage of dry and wet parts of the riverbed was evaluated and pool dimensions (width, length and depth) were recorded.

In eurheic and arheic states, in situ characterization of the water was carried out, comprising parameters as temperature $\left(\mathrm{T},{ }^{\circ} \mathrm{C}\right), \mathrm{pH}$, dissolved oxygen (DO, \% of $\mathrm{O}_{2}$ saturation) and Electrical Conductivity (EC, $\mu \mathrm{S} \mathrm{cm}^{-1}$ ) using a TROLL 9500 PROFILER XP multi parametric probe. Additionally, water was sampled and transported refrigerated in polyethylene bottles to the laboratory (67 samples), where standard methods for water chemical analyses were applied according to APHA (1995), comprising the following parameters: total nitrogen ( $\left.\mathrm{TN}, \mathrm{mg} \mathrm{N} \mathrm{L}^{-1}\right)$, nitrate $\left(\mathrm{NO}_{3}^{-}, \mathrm{mg} \mathrm{N} \mathrm{L}^{-1}\right)$, nitrite $\left(\mathrm{NO}_{2}^{-}, \mathrm{mg}-\mathrm{N} \mathrm{L}^{-1}\right)$, ammonium $\left(\mathrm{NH}_{4}^{+}\right.$, mg $\mathrm{N} \mathrm{L}^{-1}$ ), total phosphorus (TP, $\left.\mathrm{mg} \mathrm{P} \mathrm{L}{ }^{-1}\right)$, phosphate $\left(\mathrm{PO}_{4}^{3-}\right.$, $\left.\mathrm{mg} \mathrm{P} \mathrm{L}{ }^{-1}\right)$, biochemical oxygen demand after 5 days $\left(\mathrm{BOD}_{5}, \mathrm{mg} \mathrm{O}_{2} \mathrm{~L}^{-1}\right)$, organic matter (OM, $\left.\mathrm{mg} \mathrm{L}^{-1}\right)$, and turbidity (TU, NTU). In arheic conditions, the riverbed was analysed to understand whether a sub-surface connectivity could be present, being this observation further validated by the determination of in situ parameters in all pools (DO, pH, EC and T) using a multiparametric probe. According to Gallart et al. (2012), when the riverbed is alluvial some sub-surface connectivity can be present, allowing the maintenance of the pool water physicochemical characteristics during some time. On the other hand, when the riverbed is impervious, the pool waters are more vulnerable to quality deterioration. When some sub-surface connectivity was not observed and in situ parameters differed greatly among pools, separate samples were collected for posterior analysis of the remaining physicochemical parameters in laboratory, otherwise, when there was sub-surface connectivity confirmed by the in situ characterization, only one sample was transported to the laboratory.

\subsubsection{Diatoms}

During eurheic conditions, diatom samples were collected following standard protocols (AFNOR, 2003; European Committee for Standardization, 2003; INAG, 2008). In arheic conditions, when more than one pool was present, and if sub-surface connectivity was detected, only one composite sample was collected, including cobbles from the pools, with the number of cobbles collected in each pool depending on the availability of hard substrate and the pool size. When the pools differed and were not interconnected, two independent samples were collected and preserved separately. A minimum of 5 cobbles were collected at each site, to obtain sufficient biological material for the analysis; 7-10 cobbles in the case of interconnected pools.

Dry biofilm was also collected in arheic, hyporheic and edaphic conditions. For this, 10 cobbles were sampled from the middle of the channel where riffles were present during the high water condition (previous pool areas were excluded). Cobbles were cleaned with tap water to remove the coarse sand and dust, and were brushed with a toothbrush and rinsed with distilled water, similarly to the procedure carried out 

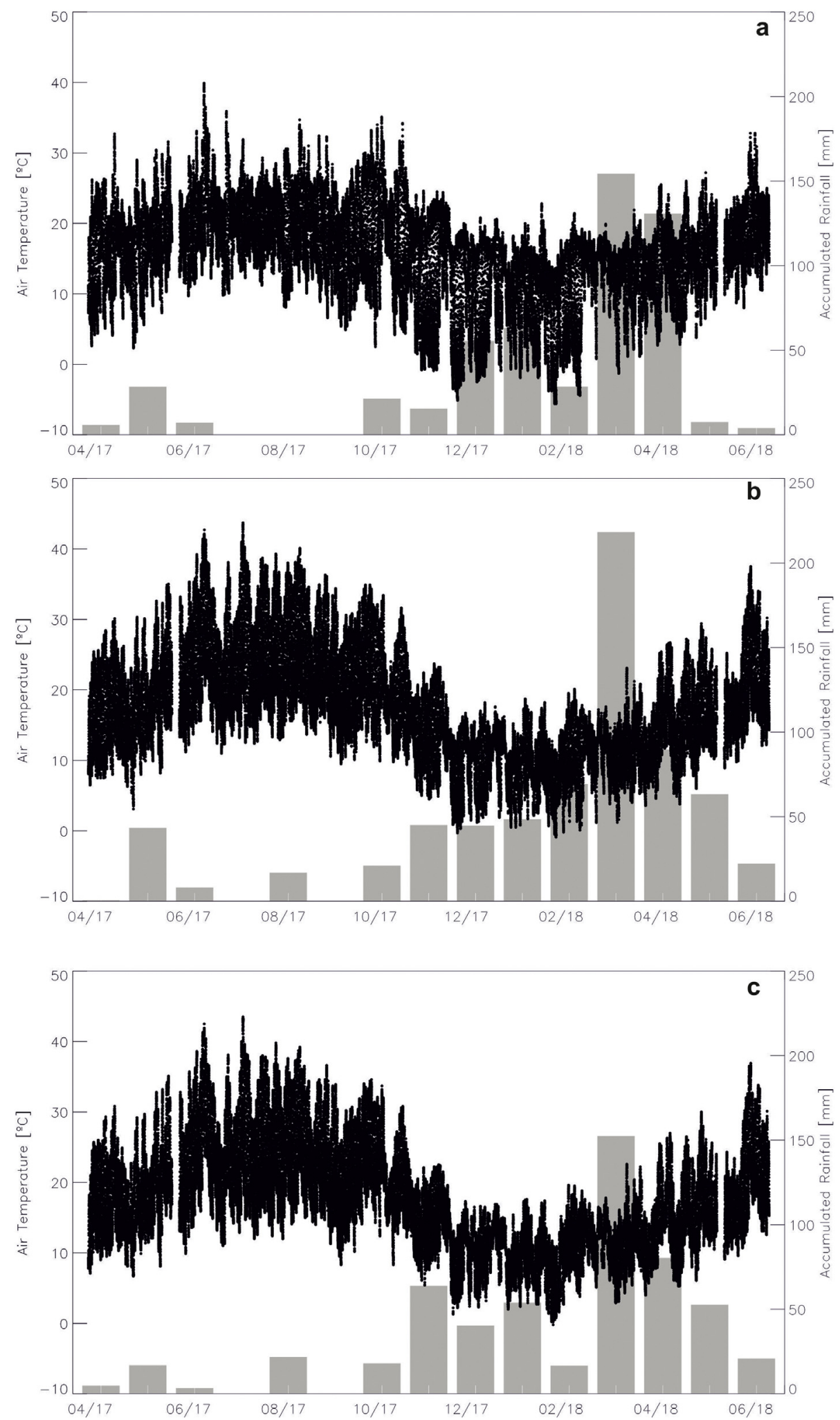

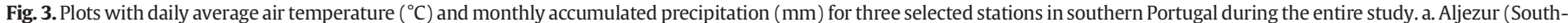
west). b. Évora (Centre). c. Beja (Centre-South).

when water was present. All samples were further preserved with formaldehyde solution ( $4 \% \mathrm{v} / \mathrm{v}$ ) immediately after sampling.

In summary, a total of 88 samples were analysed; 41 collected in eurheic conditions (in the 4 sampling campaigns in the two permanent streams, and in the remaining sites 16 in spring 2017, 9 in winter (2017/
2018) and 8 in Spring 2018); 39 samples were collected in arheic conditions, 21 in summer 2017, 10 in winter (2017/2018) and 8 in spring 2018, from which 27 were collected in pools and 12 in dry biofilm; and 8 samples were collected in dry biofilm in hyporheic conditions, 6 in summer 2017 and 2 in winter (2017/2018). 
Diatom samples were treated by oxidation using hot $\mathrm{H}_{2} \mathrm{O}_{2}$ (35\%) and dilute $\mathrm{HCl}(37 \%)$, to obtain a suspension of clean frustules after repeated rinsing and decantation with distilled water. Permanent slides were mounted in a high refractive index medium (Naphrax, Northern Biological Supplies, Ltd., UK, RI = 1.74). Diatoms were identified to species or subspecies level using light microscopy (LM) (Leica DMLB with $100 \times$ oil immersion objective, N.A. 1.40). At least 400 valves were identified and counted from each slide to estimate the relative abundance of each taxon (INAG, 2008). The identification was based on reference floras (e.g. Krammer and Lange-Bertalot, 1986, 1988, 1991a, 1991b; Blanco et al., 2010; Hofmann et al., 2011), as well as on recent bibliographic sources, including the series 'Diatoms of Europe', 'Iconographia Diatomologica', 'Bibliotheca Diatomologica' and relevant taxonomic papers, such as Reichardt (1997), Van de Vijver et al. (2011), Delgado et al. (2015, 2016) and Novais et al. (2011, 2015, 2019). Samples were analysed by a single operator to decrease possible identification error effects, which can be the main source of variability according to Prygiel et al. (2002) and Kahlert et al. (2009).

For each sample, taxa richness (S), Shannon diversity index $(\mathrm{H})$ and Pielou's evenness index $(\mathrm{J})$ were determined. Diatom taxa abundances were used to calculate the Specific Pollution Sensitivity Index (SPI) (Coste, 1982) using OMNIDIA v. 5.5 (Lecointe et al., 1993). The SPI is based on the Zelinka and Marvan (1961) formula, which consists in assigning pollution tolerance $(\mathrm{S})$ and stenoecy degree $(\mathrm{V})$ values to each taxon. Higher SPI values correspond to lower pollution. This index was selected because it was developed to assess the quality of European watercourses, it is based on the autecology of almost all known taxa, and has been recommended as a reference for Mainland Portugal (Agência Portuguesa do Ambiente, 2016). SPI values were then converted to Ecological Quality Ratios (EQR), considering the reference values for the four WFD types to which the sites belong (Agência Portuguesa do Ambiente, 2016). Taxa with relative abundance $\geq 2 \%$ were assigned to ecological guilds following the classification of Passy (2007), Berthon et al. (2011) and Rimet and Bouchez (2012) in lowprofile, high-profile, motile and planktic guilds. Furthermore, diatom taxa with relative abundance $\geq 2 \%$ were classified in terms of life-forms Rimet and Bouchez (2012), as adnate or pedunculated (among which a separation was carried out between mucilage pad and stalk), and colony-forming.

\subsection{Statistical analysis}

\subsubsection{Environmental parameters}

The water physicochemical data were log-transformed prior to the analysis and the Shapiro-Wilk normality test $(p<0.05)$ was applied. These data were first tested for correlations among the 17 environmental parameters (including the water physicochemical characterization, water flow, percentage of dry riverbed, average air temperature and accumulated precipitation), by means of Pearson correlations using STATISTICA 8.0 (StatSoft Inc, 2001). A Principal Component Analysis (PCA) (Goodall, 1954) was run to detect patterns and explore the relationships between environmental variables and samples in terms of sampling periods, sites, aquatic states and mesohabitats, based on a matrix with 15 variables $\times 67$ samples. For this, CANOCO v. 4.5 (ter Braak and Šmilauer, 2002) was used. Then, several Kruskal-Wallis One Way Analysis of Variance on Ranks (Kruskal-Wallis tests) were carried out to test whether the differences among Summer or Winter and Spring 2018 pools resulted from different morphometry (pool length, width and depth). For this, SigmaPlot 12.0 (Systat Software Inc., Chicago, IL) was used.

\subsubsection{Diatoms}

Only diatom taxa reaching an abundance $>2 \%$ in at least one sample were included, to increase the statistical power of the analysis (192 diatom taxa in total).
In order to test whether the composition of diatom assemblages reflects the aquatic states, a non-metric multidimensional scaling (nMDS) ordination was applied, based on a matrix with 192 diatom taxa $\times 88$ samples. Data were arc sin square root transformed (Bray-Curtis distance; minimum stress 0.01 ; Kruskal fit scheme). In nMDS, closer points correspond to sites similar in species composition. Subsequently, statistical differences in diatom assemblages were tested for the aquatic regimes, sampling periods, aquatic states and mesohabitat by the nonparametric Analysis of Similarity (ANOSIM; Bray-Curtis distance, 999 permutations) based on species abundances. ANOSIM is a randomization-based multivariate analysis used to test significant differences between previously defined groups, based on any distance measure (Clarke and Ainsworth, 1993). The ANOSIM returns a dissimilarity $\mathrm{R}$ value, which is scaled between -1 and +1 , with a value of zero (or near zero) representing the null hypothesis of no differences among samples, its magnitude depending on the amount by which samples differ (Clarke and Ainsworth, 1993). The percentage breakdown of average dissimilarity between the groups was determined by means of SIMPER analysis, using the Bray-Curtis dissimilarity index (Clarke and Gorley, 2001). nMDS, SIMPER and ANOSIM analyses were performed using PRIMER Version 5.2.0 (Clarke and Gorley, 2001).

In order to test whether diatom metrics and ecological guilds reflect differences between aquatic regimes of the streams, sampling periods, aquatic states and mesohabitats, Linear Mixed Models were fitted to our data, considering Stream as a Random Factor, using the R version 3.6.2 (2019-12-12), package: ImerTest R Core Team, 2019. Normality was previously checked at $5 \%$ significance level by Shapiro-Wilk test with $p$-values adjusted by the Holm method, and we could not reject normality for all dependent variables. In every initial model four fixed factors were considered: Aquatic regime + Aquatic state + Mesohabitat + Sampling period, then the models were simplified using the backward elimination of non-significant effects. In the first and in the last model an Analysis of Variance with Satterthwaite's method was performed, and $p$-values for the last model are reported.

Spearman rank order correlations were calculated to explore possible correlations between diatoms (expressed as taxa richness, Shannon diversity and Pielou's evenness indices and SPI) and environmental parameters (physicochemical, water flow and percentage of dry riverbed), using STATISTICA 8.0 (StatSoft Inc, 2001).

The indicator value (IndVal) method was used to identify the key species of each aquatic state through time and at each mesohabitat, taking into account also the previous PCA results for environmental parameters (Dufrêne and Legendre, 1997), using PC-Ord 6.0 (MjM Software Ltd., 217-219 Hamstel Road, Southend on Sea Essex SS2 4LB). IndVals for each species are provided, based on the combination of the specificity and fidelity of occurrence of a taxon in a group. The statistical significance of the species IndVal was determined using Monte Carlo random permutation tests.

The updated version of the Rote List by Lange-Bertalot and Steindorf (1996) and the taxa from the Rote List considered by Hofmann et al. (2011) for the German watercourses, both retrieved from the OMNIDIA v. 5.5 database (Lecointe et al., 1993) were used to check the conservation status and the ecology for the diatom taxa with relative abundance $\geq 2 \%$ in at least one sample.

\section{Results}

\subsection{Meteorological characterization}

The study period comprises two meteorological Springs (2017 and 2018), one Summer (2017) and one Winter (2017/2018). In the Summer period, the precipitation was negligible, therefore no map is presented. The derived maps of air temperature and precipitation (section 2.2) result in a first Spring period: 1st April to 26th May 2017; a Summer period: 18th August to 11th October 2017; a Winter period: 15th December 2017 to 19th February 2018; and a second 
Spring period: 9th April to 14th June 2018. Fig. 1 shows the results for air temperature and for comparison purposes the scale for both Springs is the same (Fig. 1a and d). Spring 2017 presents minimum values around $15{ }^{\circ} \mathrm{C}$ in the southwest region and maximum values around $19^{\circ} \mathrm{C}$ in the northeast region, whilst the Spring 2018 presents minimum values around $12{ }^{\circ} \mathrm{C}$ in higher altitude regions and maximum values around $17^{\circ} \mathrm{C}$ in lower altitude regions. Thus, it is evident that the Spring 2017 was hotter than the Spring 2018. Regarding the accumulated precipitation for these periods, Fig. 2a and c show that precipitation was higher in the northern and western region for Spring 2017 whilst in 2018 was more intense in the northeast region (values up to $80 \mathrm{~mm}$ ) and a decrease gradient towards the south and southwest. In the southern region, the precipitation was low for both Springs periods with values between 10 and $20 \mathrm{~mm}$. It should be noted, however, that throughout spring 2018 precipitation was much higher, particularly in March as shown in Fig. 3. Due to the exceptionally high accumulated precipitation in March, the soil water content in the 2018 spring period was higher which can explain, at least partially, why the temperatures were lower. The average temperature map for the Summer 2017 period (Fig. 1b) shows a clear west-to-east pattern where lower values were found near the coastline, western side of the region, and higher values were found on the eastern part of the region. This longitudinal contrast reaches a remarkable value of around $7{ }^{\circ} \mathrm{C}$ between extremities, which are $200 \mathrm{~km}$ distant from each other. During the Winter 2017/2018 period (Fig. 1c), the average temperature was higher near the west and south coastline and there was a lower temperature in the interior region with minimum values around $7{ }^{\circ} \mathrm{C}$ in the northeast region. The accumulated precipitation (Fig. $2 \mathrm{~b}$ ) was higher near the coast and northern part of the region (with values of $80 \mathrm{~mm}$ ) with a small exception on the northwest region. On the contrary, in the interior and especially in the southeastern region the accumulated precipitation was very low with minimum values of around $15 \mathrm{~mm}$.

In the three selected meteorological stations (Fig. 3) the difference in average temperature between Springs 2017 and 2018 is visible, with higher values in 2017. This is also seen in the map for southern Portugal (Fig. 1a and d). However, among the three stations, higher temperature values are detected in the South and Centre stations (Fig. 3b and c, Évora and Beja) due to larger distance to the coastline. Also the accumulated precipitation differed between years, with lower values detected in 2017 for the three stations, it is worth noticing that in 2017 the lower accumulated precipitation continued until November 2017 for the three stations and higher accumulated rainfall in March and April 2018 again for the three stations.

\subsection{Environmental parameters: spatial and temporal gradients}

Water physicochemical conditions were analysed during the eurheic and arheic states, that is, when water was present in the channel. Descriptive statistics of the environmental parameters characterizing aquatic states through time are presented in Table S4. In this table it can also be noted that sites are not subjected to high contamination, since in eurheic conditions only DO is below the limit for good ecological status in Spring 2018, and TP exceeds the limit for the good ecological status $\left(>0.13 \mathrm{mg} \mathrm{L}^{-1}\right)$ in 7 sites in Winter 2017/2018 and in 10 sites in Spring 2018 (according to Agência Portuguesa do Ambiente, 2016).

The results of the PCA (Fig. 4), show that the first two axes accounted for the $82.1 \%$ of the total variance. In particular, the first axis explains $63.1 \%$ of the total variance and represents a gradient of flow intermittency; it is positively correlated with dry riverbed percentage and negatively correlated with water flow. Accordingly, samples collected in eurheic conditions during all sampling seasons are located in the negative part of the axis, whereas samples collected in arheic conditions (in Summer 2017, Winter 2017/2018 and Spring 2018) are located in the positive part. The second axis accounted for $18.1 \%$ variance and represented a gradient of nutrient enrichment, turbidity and temperature (both air and water) (Fig. 4). Along this second axis, we may distinguish

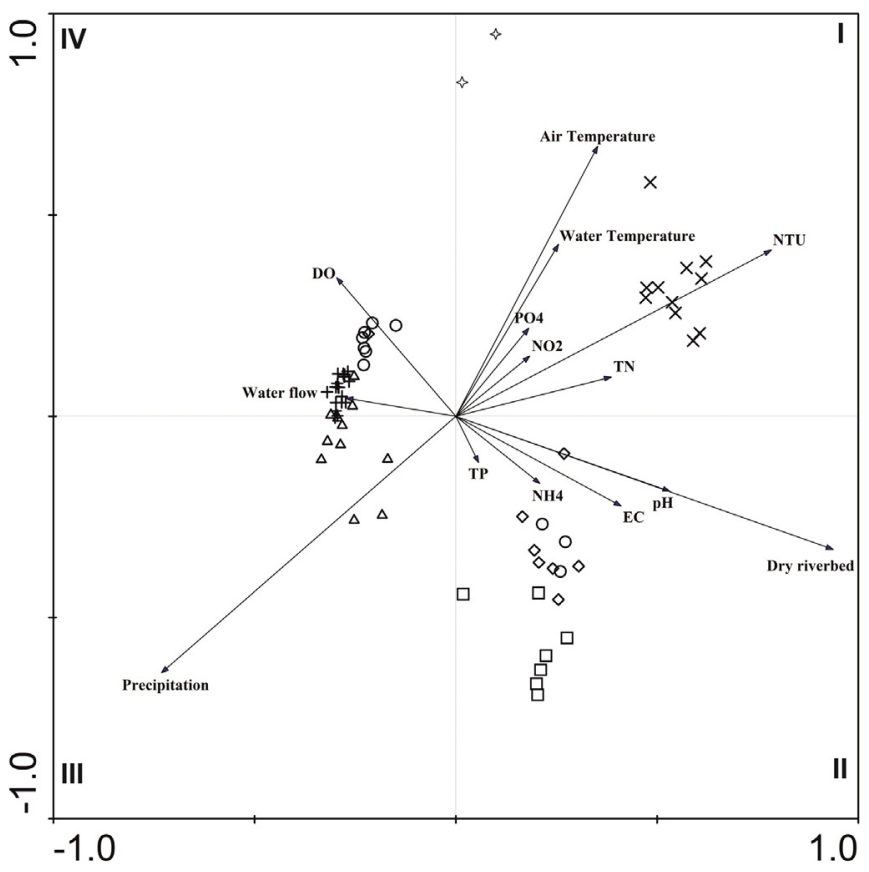

Fig. 4. Principal Component Analysis biplot for the first two components, representing the distribution of samples according to environmental gradients. Aquatic states and seasons are represented by different shapes. "+" = eurheic in Spring 2017, star = eurheic in Summer 2017, triangle = eurheic in Winter 2017/2018, circle = eurheic in Spring 2018 $X=$ arheic in Summer 2017, square $=$ arheic in Winter 2017/2018, diamond $=$ ahreic in Spring 2018.

samples collected during arheic conditions in Summer, driven by higher air and water $\mathrm{T}, \mathrm{NTU}, \mathrm{PO}_{4}^{3-}, \mathrm{NO}_{2}^{-}$and $\mathrm{TN}$ values (in the positive part of the axis) from Winter and Spring samples, mainly driven by EC, $\mathrm{NH}_{4}^{+}$ and TP, in the negative part of the axis. Therefore, the two PCA axis reflect the succession in aquatic states through time, visible in the four PCA quadrants, with samples collected in arheic conditions in Summer 2017 visible in quadrant I, Winter 2017/2018 and Spring 2018 arheic conditions in quadrant II, eurheic conditions in Spring 2017, Winter 2017/2018 and Spring 2018 in quadrants III and IV.

Given that samples collected in Summer 2017 pools differed from Winter 2017/2018 and Spring 2018 pools, a Kruskal-Wallis test was carried out to explore whether these differences reflected changes in pool morphology among seasons. However, no differences were detected in pool size: length $(H=5.905$ with 3 degrees of freedom, $p=0.116)$, width $(H=3.518$ with 3 degrees of freedom, $p=0.318)$, and depth ( $H=1.770$ with 3 degrees of freedom, $p=0.621$ ), therefore, detected changes reflect statistically significant differences in the physicalchemical characteristics of the pools, namely the higher $\mathrm{T}, \mathrm{TN}, \mathrm{PO}_{4}^{3-}$, $\mathrm{NO}_{2}^{-}, \mathrm{NO}_{3}^{-}, \mathrm{TU}, \mathrm{OM}$ and lower $\mathrm{NH}_{4}^{+}$detected in Summer 2017 pools.

\subsection{Diatoms}

\subsubsection{Diatom assemblages}

A total of 396 diatom taxa were identified in the dataset, from which 291 were present with relative abundance $>1 \%$, and 192 with relative abundance $>2 \%$ in at least one sample. These 396 taxa were comprised in 77 genera, from which Nitzschia (61 taxa), Gomphonema (40 taxa), Navicula (40 taxa), Fragilaria (21 taxa), Pinnularia (13 taxa), Planothidium (12 taxa) and Eunotia (11 taxa) were the most specious, whilst the remaining 70 genera had $<10$ species, among which 31 genera included only one species. The most abundant species (relative abundance $>20 \%$ ) occurring in $>50 \%$ of all samples were: Cocconeis euglypta Ehrenberg (55\% of samples), Achnanthidium minutissimum (Kützing) Czarnecki (80\%), Planothidium frequentissimum (LangeBertalot) Lange-Bertalot (61\%), Nitzschia paleacea (Grunow) Grunow 
(54\%), Navicula veneta Kützing (68\%), Nitzschia inconspicua Grunow (58\%), Amphora pediculus (Kützing) Grunow (52\%), Ulnaria biceps (Kützing) Compère (53\%). Other taxa are abundant ( $>20 \%$ maximum relative abundance) in at least one sample, but not widely distributed in the dataset, as Epithemia adnata (Kützing) Brébisson (70\% maximum relative abundance, present in $41 \%$ of samples), Pseudostaurosira sp. 1 ( $48 \%$ maximum relative abundance, present in $38 \%$ of samples), Fragilaria socia (J.H.Wallace) Lange-Bertalot (47.6\% maximum relative abundance, present in only 3\% of samples), Nitzschia incognita Legler \& Krasske ( $45.5 \%$ maximum relative abundance, present in only $2 \%$ of samples), Fragilaria pectinalis (O.F.Müller) Gray (40.7\% maximum relative abundance, present in $10 \%$ of samples), Platessa stewartii (Patrick) Potapova (38.8\% maximum relative abundance, present in $19 \%$ of samples), Encyonopsis sp. 1 (36.4\% maximum relative abundance, present in $2 \%$ of samples), Fragilaria tenera (W.Smith) Lange-Bertalot (34\% maximum relative abundance, present in $10 \%$ of samples), Aulacoseira granulata (Ehrenberg) Simonsen (30.75\% maximum relative abundance, present in $11 \%$ of samples), Staurosirella pinnata (Ehrenberg) D.M.Williams \& Round (30.4\% maximum relative abundance, present in $6 \%$ of samples), Encyonopsis subminuta Krammer \& E.Reichardt (28.3\% maximum relative abundance, present in $5 \%$ of samples), Nitzschia cf. inconspicua Grunow (28\% maximum relative abundance, present in $15 \%$ of samples), Punctastriata sp. (26.8\% maximum relative abundance, present in 6\% of samples), Gomphonema tergestinum (Grunow) Fricke (25.6\% maximum relative abundance, present in 35\% of samples), Pseudostaurosira elliptica (Schumann) Edlund, E.Morales \& Spaulding (23.4\% maximum relative abundance, present in $20 \%$ of samples), Navicula gregaria Donkin (23.1\% maximum relative abundance, present in 39\% of samples), Gomphonema sp. 3 (21.7\% maximum relative abundance, present in $2 \%$ of samples). The maximum relative abundance and frequency of each taxon per aquatic state through time are presented in the Supplementary Material (Table S5).

The nMDS analysis (2D ordination plots in Fig. 5) presented a stress level (indicator of the adequacy of the representation) of 0.23 , which is below the limit for a potentially useful 2-D representation (0.25); and the 3D stress level of 0.15 . Even though the 3-D representation would be more appropriate, due to the lower stress value, this would make the picture extremely complex, therefore, for the ease of interpretation only the 2-D representation was used. The nMDS ordination plots of samples, based on diatom assemblages, for the analysed factors (aquatic regime, sampling period, aquatic states and mesohabitats) did not present clear patterns (Fig. 5). Therefore, considering also the high stress level of the nMDS ordination plot (close to the limit for a useful 2-D representation), further ANOSIM and SIMPER analyses were carried out to verify our hypotheses, namely to understand whether diatom assemblages reflected: 1 ) aquatic regime of the streams; 2 ) sampling period; 3) aquatic states, confirmed in the PCA ordination for the environmental parameters; and 4) the mesohabitats (i.e. dry biofilm; samples collected in pools; or samples collect in the whole stretch following standard methods).

The ANOSIM and SIMPER analyses (Table 1) did not present high Global $\mathrm{R}$ values, even though it was statistically significant with $p<0.001$ for all the factors. Pairwise comparisons between groups revealed that diatom assemblages:
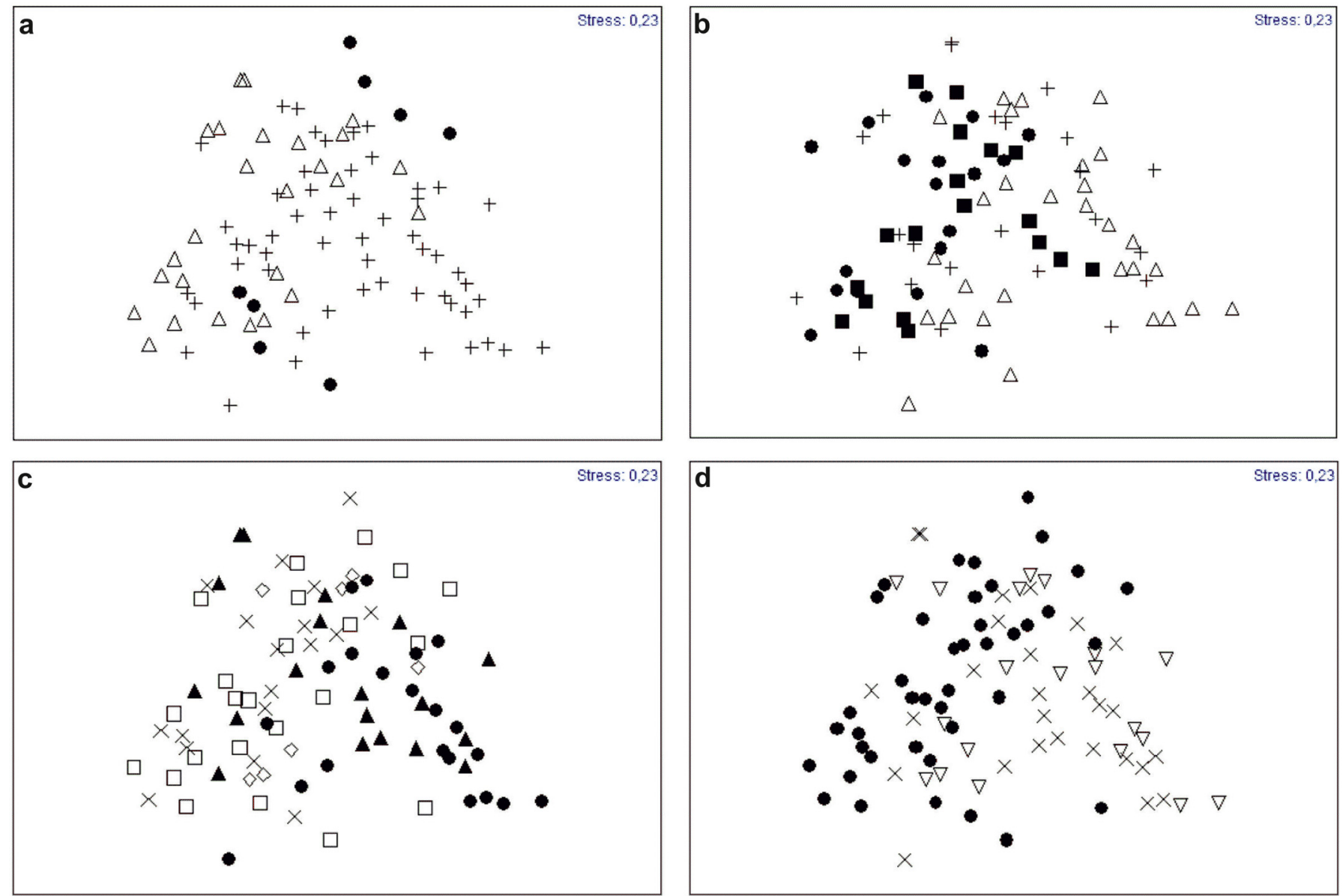

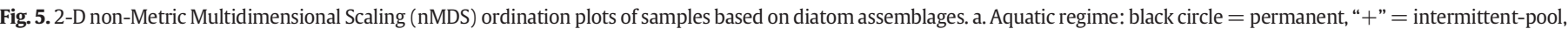

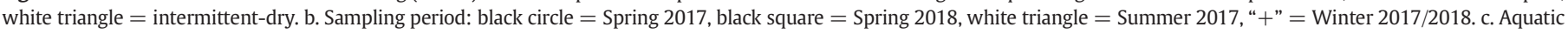

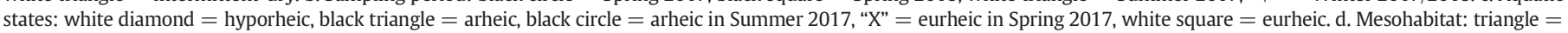
dry biofilm, black circle = flowing water, " $\mathrm{X}$ " = pool. 
Table 1

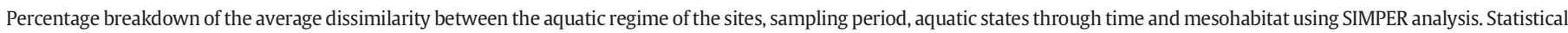

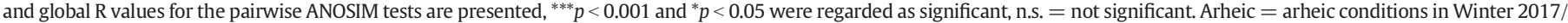
2018 and Spring 2018; Eurheic = eurheic conditions in Spring 2018, Winter 2017/2018 and Summer 2017.

\begin{tabular}{|c|c|c|c|c|c|}
\hline Factors & Groups & Average similarity (\%) & Average dissimilarity (\%) & $\begin{array}{l}\text { ANOSIM } \\
\text { (statistical R) }\end{array}$ & $\begin{array}{l}\text { ANOSIM } \\
\text { (Global R) }\end{array}$ \\
\hline \multirow[t]{3}{*}{ Aquatic regime } & Intermittent-dry $(n=26)$ & $19.66 \%$ & Dry $/$ pool $=83.27 \%$ & $R=0.156^{* * *}$ & \multirow[t]{3}{*}{ Global $R=0.207^{* * *}$} \\
\hline & Intermittent-pools $(n=54)$ & $19.36 \%$ & Dry $/$ permanent $=85.77 \%$ & $\mathrm{R}=0.342^{* * *}$ & \\
\hline & Permanent $(n=8)$ & $33.25 \%$ & Pool/permanent $=86.08 \%$ & $\mathrm{R}=0.303^{* * *}$ & \\
\hline \multirow[t]{6}{*}{ Sampling period } & Spring $2017(n=18)$ & $22.75 \%$ & Summer 2017/Winter 2017/2018 = 84.46\% & $R=0.133^{* * *}$ & \multirow[t]{6}{*}{ Global $R=0.124^{* * *}$} \\
\hline & Summer $2017(n=29)$ & $18.80 \%$ & Summer $2017 /$ Spring $2018=82.42 \%$ & $R=0.155^{* * *}$ & \\
\hline & Winter $2017 / 2018(n=23)$ & $15.28 \%$ & Winter $2017 / 2018 /$ Spring $2018=81.96 \%$ & $R=-0.022$ n.s. & \\
\hline & Spring $2018(\mathrm{n}=18)$ & $22.21 \%$ & Summer $2017 /$ Spring $2017=85.16 \%$ & $\mathrm{R}=0.303^{* * *}$ & \\
\hline & & & Winter $2017 / 2018 /$ Spring $2017=83.55 \%$ & $R=0.075^{*}$ & \\
\hline & & & Spring $2017 /$ Spring $2018=76.73 \%$ & $R=-0.011$ n.s. & \\
\hline \multirow[t]{10}{*}{ Aquatic state } & Hyporheic $(\mathrm{n}=8)$ & $21.01 \%$ & Hyporheic/Arheic $=81.47 \%$ & $R=0.083$ n.s. & \multirow[t]{10}{*}{ Global $R=0.174^{* * *}$} \\
\hline & Arheic $(n=18)$ & $19.27 \%$ & Hyporheic/Eurheic $=82.15 \%$ & $R=-0.012$ n.s. & \\
\hline & Arheic Summer $(n=21)$ & $20.94 \%$ & Arheic/Eurheic $=84.09 \%$ & $R=0.138^{*}$ & \\
\hline & Eurheic $(\mathrm{n}=23)$ & $18.52 \%$ & Hyporheic/Eurheic Spring $2017=79.08 \%$ & $R=0.118$ n.s. & \\
\hline & Eurheic Spring $2017(\mathrm{n}=18)$ & $22.75 \%$ & Arheic/Eurheic Spring $2017=83.33 \%$ & $\mathrm{R}=0.2^{*}$ & \\
\hline & & & Eurheic/Eurheic Spring $2017=79.18 \%$ & $\mathrm{R}=-0.01 \mathrm{n} . \mathrm{s}$ & \\
\hline & & & Hyporheic/Arheic Summer $2017=82.45 \%$ & $R=0.154$ n.s. & \\
\hline & & & Arheic/Arheic Summer $2017=81.62 \%$ & $R=0.125^{*}$ & \\
\hline & & & Eurheic/Arheic Summer $2017=86.05 \%$ & $\mathrm{R}=0.293^{* * *}$ & \\
\hline & & & Eurheic Spring 2017/Arheic Summer $2017=86.59 \%$ & $\mathrm{R}=0.413^{* * *}$ & \\
\hline \multirow[t]{3}{*}{ Mesohabitat } & Dry biofilm $(n=20)$ & $18.30 \%$ & Dry $/$ pool $=81.24 \%$ & $R=0.027$ n.s. & \multirow[t]{3}{*}{ Global $\mathrm{R}=0.17^{* * *}$} \\
\hline & Cobbles in pools $(n=27)$ & $19.57 \%$ & Dry $/$ with flow $=83.68 \%$ & $\mathrm{R}=0.195^{* * *}$ & \\
\hline & Cobbles with flow $(n=41)$ & $20.47 \%$ & Pool/with flow $=84.79 \%$ & $\mathrm{R}=0.223^{* * *}$ & \\
\hline
\end{tabular}

1) reflected some differences in the aquatic regime of the selected sites, distinguishing between the 2 permanent sites (Barranquinho and Barranco de João Dias) from the intermittent-pool $(R=0.303$, $p<0.05)$ and the intermittent-dry $(R=0.342, p<0.001)$ sites, whilst a high overlap was detected between intermittent-pool and intermittent-dry sites, as seen in the low $\mathrm{R}$ value $(R=0.156$, $p<0.001)$. In the ANOSIM analysis, a low $\mathrm{R}$ value means that the similarities are greater within groups than between groups, and the significance of the $\mathrm{R}$ statistic is determined by permutation. In this case, there is a statistical significance of the $\mathrm{R}$ value, even though it is low.

2) When the sampling period was considered, diatom assemblages only separated the samples collected in Spring 2017 from Summer $2017(\mathrm{R}=0.303, p<0.001)$.

3) Significant differences were detected between aquatic states, distinguishing eurheic conditions in Spring 2017 from arheic conditions in Summer $2017(R=0.413, p<0.001)$ and arheic conditions in other seasons $(R=0.2, p<0.05)$, and ahreic conditions in Summer 2017 and eurheic conditions in all seasons except Spring 2017 $(R=0.293, p<0.001)$.

4) Diatom assemblages reflected the mesohabitats, differentiating between samples collected in sites with flowing water and pools $(R=0.223, p<0.001)$ and dry biofilm $(R=0.195, p<0.001)$, however, no differences were detected between samples collected in hard substrate from pools and dry biofilm.

\subsubsection{Diversity indices and specific pollution sensitivity index (SPI)}

The average values and standard deviations of biological indices, namely taxa richness, Shannon diversity and Pielou's evenness, and that of SPI are reported in Table S6 for each category of aquatic regime, aquatic state, sampling period and mesohabitat. To test the hypothesis that diversity indices and SPI reflect: 1) the aquatic regimes, 2) the sampling period, 3) the changes in aquatic states through time, and 4) the mesohabitats, Linear Mixed Models were fitted to our data. These analyses revealed no differences for species richness between the diverse factors. Shannon diversity index reflected mesohabitat differences $(p$ value $=2.7 \%$ ), distinguishing samples collected under flowing water from those in pools ( $p$-value $=0.7 \%$ ), with higher values in pools (see Table S6); Pielou's Evenness index $(p$-value $=0.8 \%$ ) also reflected mesohabitat differences, distinguishing cobbles sampled in pools from samples collected under flowing conditions ( $p$-value $=0.9 \%$, and from dry biofilm samples ( $p$-value $=0.5 \%$ ), with highest values detected in pools (see Table S6).

Interestingly, SPI was the variable that differed most, distinguishing both the sampling period and the mesohabitat ( $p$-value $=0.2 \%$ for both variables models). The SPI differed between Spring 2018 and Summer 2017 ( $p$-value $=2.9 \%)$ and Winter 2017/2018 ( $p$-value $=0.05 \%)$, with highest values detected in Spring 2018. Regarding the mesohabitat, differences were detected only between dry biofilm samples and cobbles collected in pools ( $p$-value $=0.6 \%$ ), with lowest SPI values in the pools (Table S6).

Since differences were detected for some biological indices among groups, further correlations were carried out to understand if the detected differences reflected the water physicochemical characteristics, water flow or the intermittency status measured by the percentage of dry riverbed. Only significant positive weak correlations were detected between the Shannon diversity and Pielou's Evenness indices and $\mathrm{pH}$ $(r=0.30)$, and between Pielou's Evenness index and percentage of dry riverbed $(r=0.37)$. Significant negative weak correlations were detected between species richness and $\mathrm{NO}_{3}^{-}(r=-0.30)$, Pielou's Evenness index and between water flow $(r=-0.36)$, SPI and $\mathrm{pH}(\mathrm{r}=$ $-0.36)$, EC $(r=-0.41), \mathrm{NH}_{4}^{+}(\mathrm{r}=-0.41), \mathrm{TN}(r=-0.32)$ and percentage of dry riverbed $(\mathrm{r}=-0.41)$.

\subsubsection{Functional metrics}

Since the changes in aquatic states through time reflect very diverse conditions in terms of nutrient availability and flow (according to the PCA ordination results), further analyses were carried out to verify if these changes were reflected in the relative abundance of diatom ecological guilds and life-forms. Fig. 6 shows that the low-profile guild dominated in eurheic conditions, followed by the high-profile guild in Spring 2017 and by the motile in the remaining periods; during arheic conditions, diatom assemblages were dominated by the motile and low-profile guilds, the low-profile guild having higher relative abundance in Summer 2017 than the motile guild. A first analysis revealed that most of the diatom taxa identified in this study are solitary, not forming colonies (presented in Fig. 7). Taking this into account, and the fact that there is a high proportion of diatoms belonging to the high and low-profile guilds, further tests were carried out to disentangle the type of attachment to the substrate, either adnate (attachment by the valve face or girdle view) or pedunculate (attachment by a pole), 


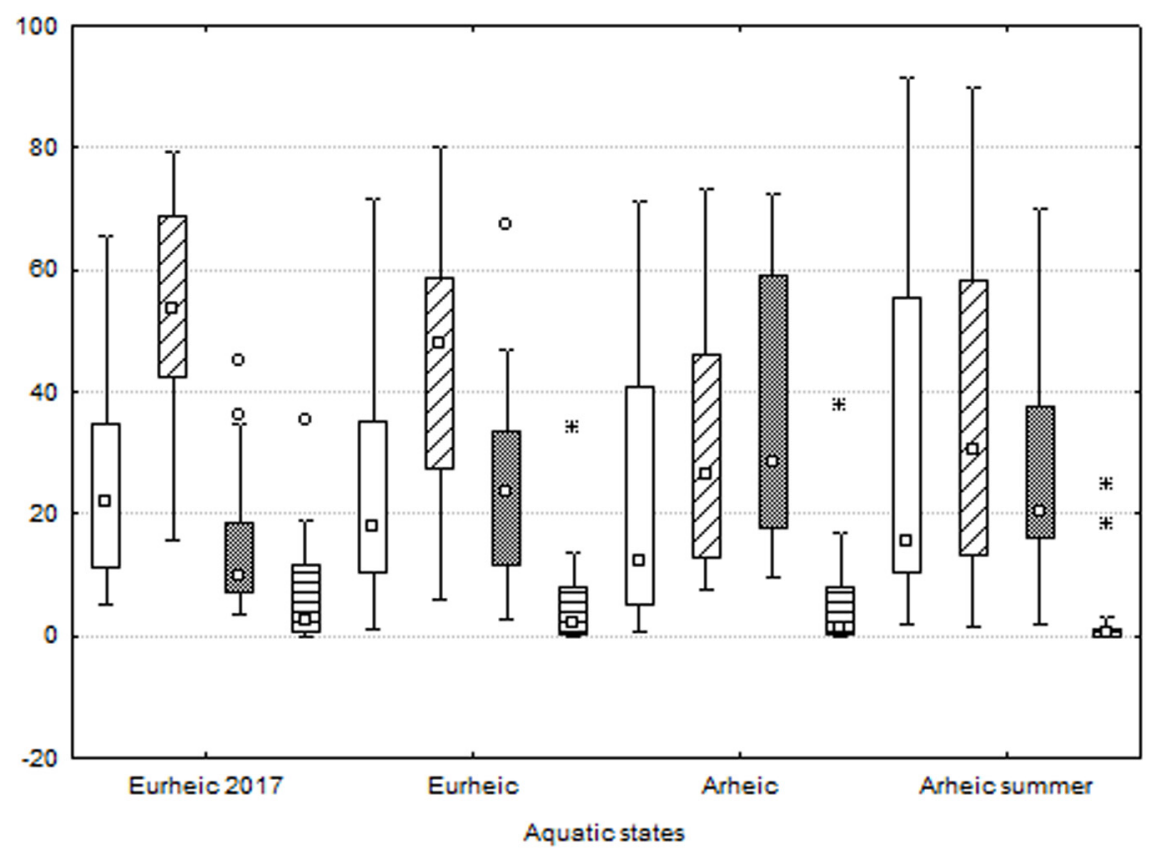

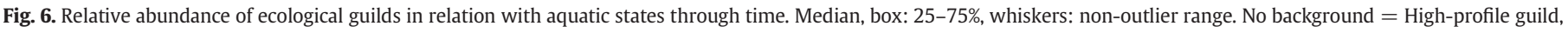

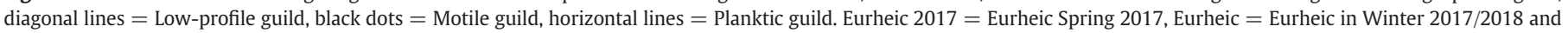
Spring 2018, Arheic = Arheic in Winter 2017/2018 and Spring 2018, Arheic Summer = Arheic Summer 2017.

as characterized by Rimet and Bouchez (2012). Fig. 8 shows that pedunculate forms dominate during the entire study, even though their abundance decreased in arheic conditions, especially in Winter 2017/2018 and Spring 2018 periods (when the motile forms presented the highest values, as seen in Fig. 6). Since pedunculate forms dominated, further characterization was carried out (according to Rimet and Bouchez, 2012), to understand if there was a dominance of cells forming a mucilage pad (mucilage is produced on a pole that sticks to the substrate, e.g. Diatoma spp.) or a stalk (produced through apical pore fields, e.g. Achnanthidium spp.), related with different aquatic states through time. In Fig. 9 it is observed that cells producing a stalk dominated in eurheic conditions, whilst their relative abundance decreased in arheic conditions. A slight increase of species producing a mucilage pad was detected in Summer 2017 (when they surpassed the relative abundance of mucilage stalk producing species). In Fig. 10 it is clear that the lowprofile and the motile guilds reflected changes in habitat, with a decrease in the low-profile and an increase in the motile guild abundance with the pool formation.

To test the hypothesis that the relative abundance of ecological guilds reflects: 1 ) the aquatic regimes, 2) the sampling period, 3 ) the

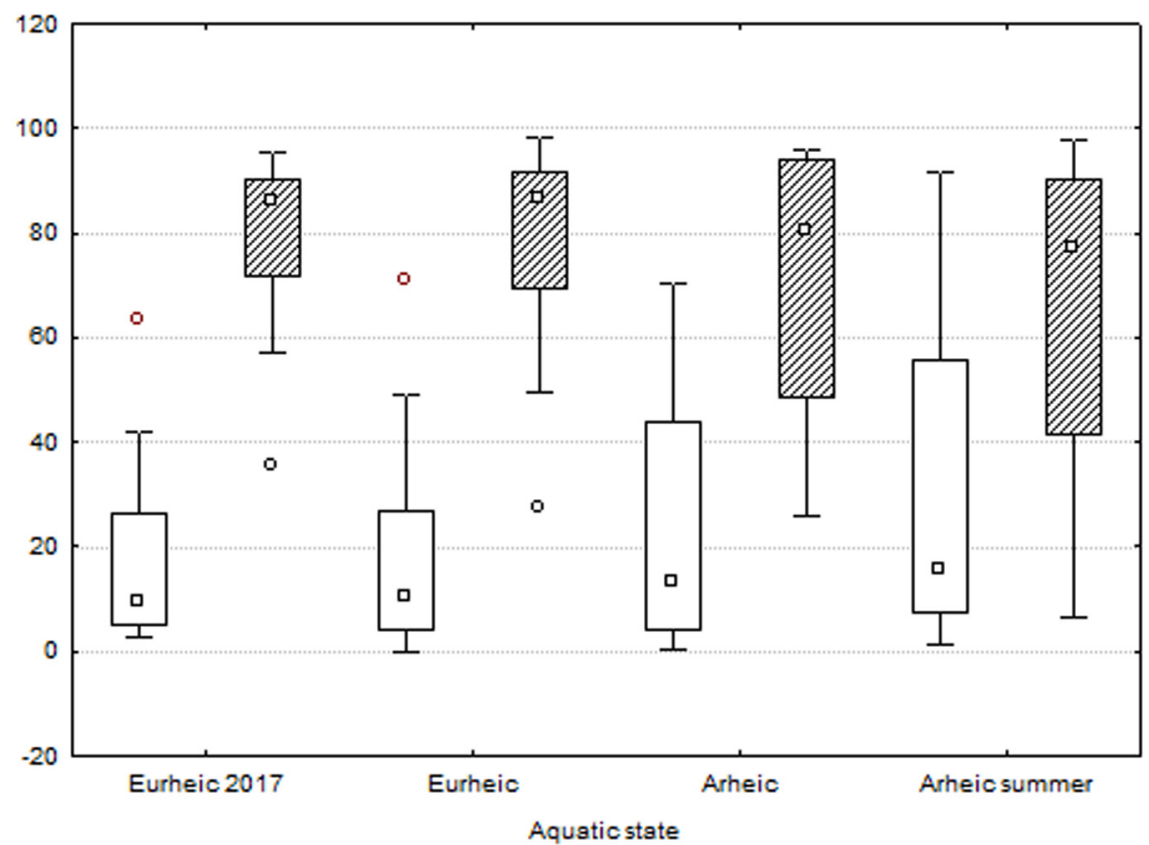

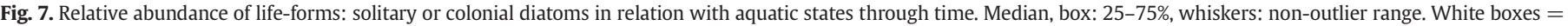

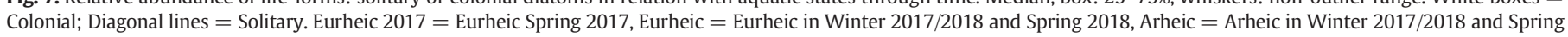
2018, Arheic Summer = Arheic Summer 2017. 


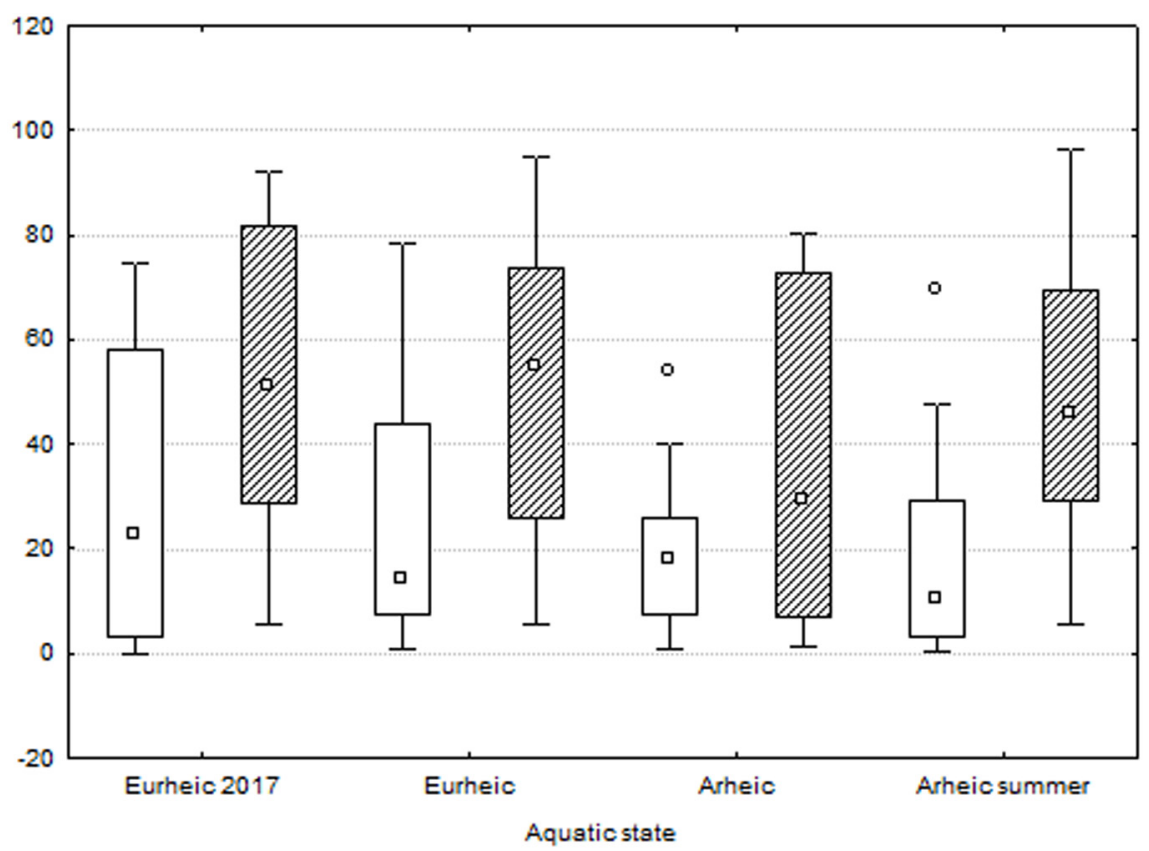

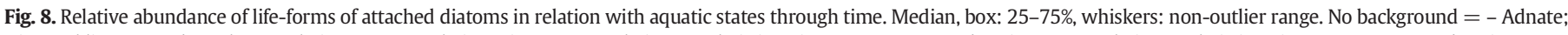

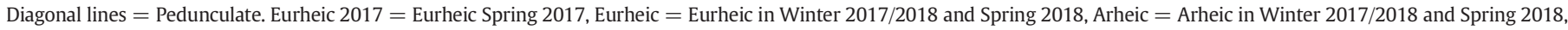
Arheic Summer = Arheic Summer 2017.

changes in aquatic states through time, and 4) the mesohabitats, Linear Mixed Models were fitted to our data. These analyses revealed no differences for the high-profile (last eliminated factor: Mesohabitat with a $p$ value $=10 \%$ ) and planktic guilds (last eliminated factor: Aquatic.state with a $p$-value $=9.4 \%$ ). The low-profile guild differed between seasons $(p$-value $=0.03 \%)$, with both springs being similar and significatively different from Summer 2017 ( $p$-value $=0.6 \%$ for Spring 2017, $p$ value $=1.2 \%$ for Spring 2018) and Winter 2017/2018 ( $p$-value $=$ $0.02 \%$ for Spring 2017, $p$-value $=0.06 \%$ for Spring 2018), which are similar to each other. Also the motile guild differed between seasons ( $p$ - value $=0.2 \%$, with both springs being similar and significatively different from Summer 2017 ( $p$-value $=0.02 \%$ for Spring 2017, $p$-value $=$ $3.4 \%$ for Spring 2018) and Winter 2017/2018 ( $p$-value $=0.002 \%$ for Spring 2017, $p$-value $=0.3 \%$ for Spring 2018), which are similar to each other.

\subsubsection{Indicator species}

Considering the differences detected in diatom assemblages and SPI between aquatic states through time (according to the groups resulting from the PCA ordination for the environmental

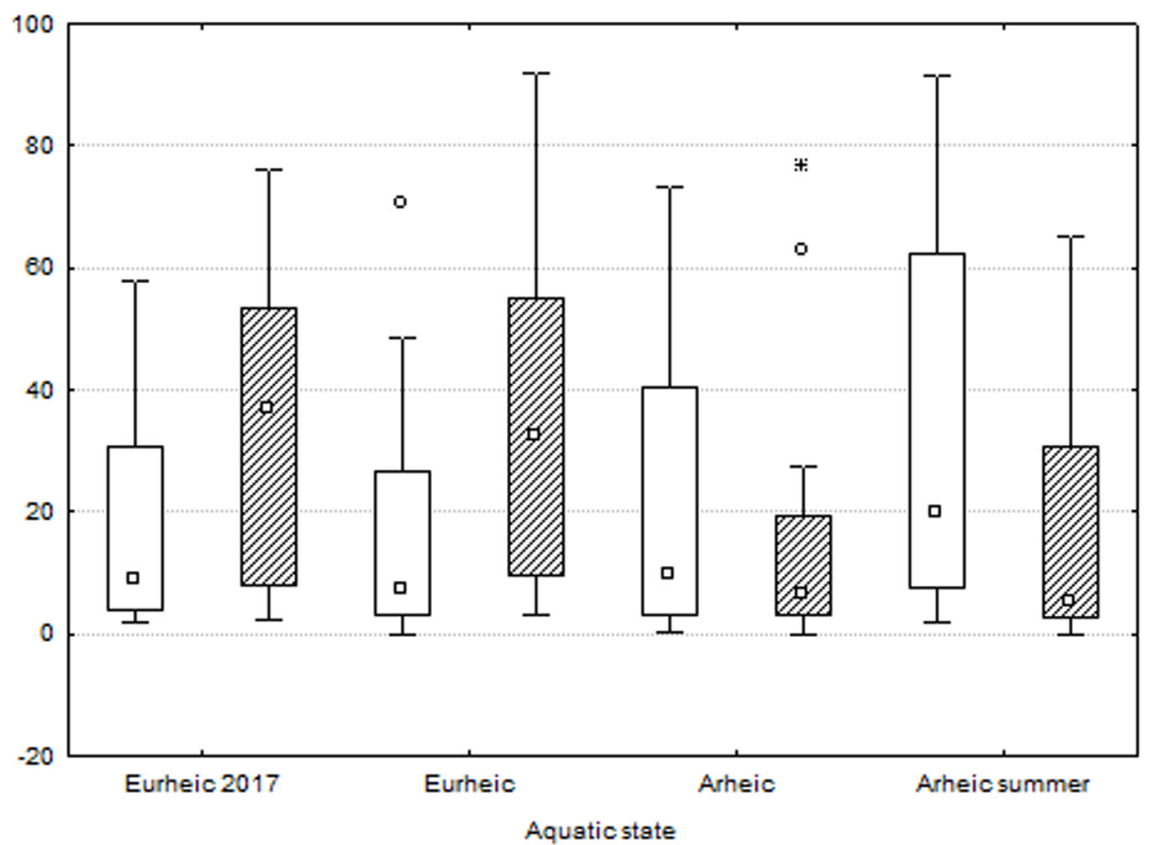

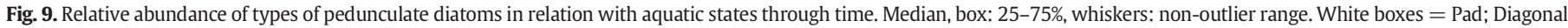

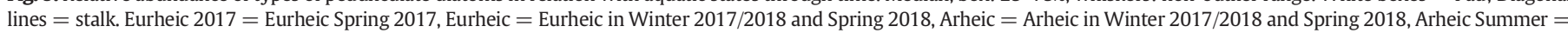
Arheic Summer 2017. 


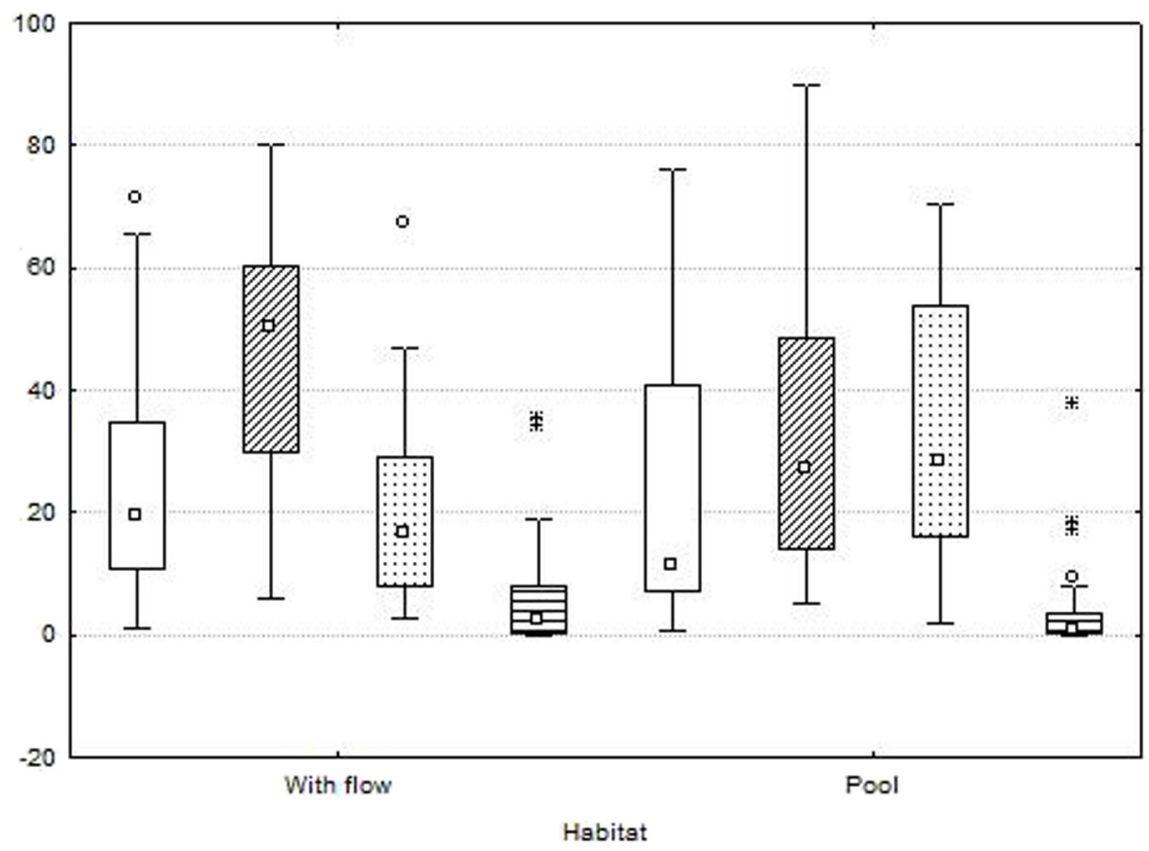

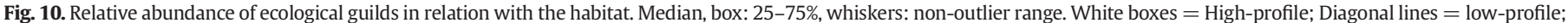
dots $=$ motile; horizontal lines $=$ planktic.

Table 2

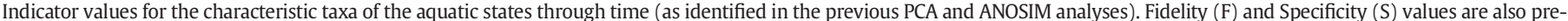

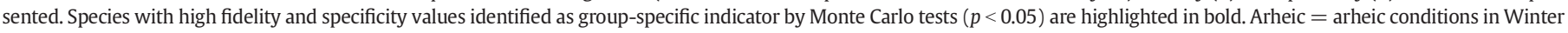
2017/2018 and Spring 2018; Eurheic = eurheic conditions in Spring 2018, Winter 2017/2018 and Summer 2017.

\begin{tabular}{|c|c|c|c|c|c|c|c|c|c|c|c|c|c|}
\hline \multirow[b]{2}{*}{ Taxon name } & \multirow[b]{2}{*}{ Taxon code } & \multicolumn{3}{|c|}{ Arheic } & \multicolumn{3}{|c|}{$\begin{array}{l}\text { Arheic Summer } \\
2017\end{array}$} & \multicolumn{3}{|c|}{ Eurheic } & \multicolumn{3}{|c|}{$\begin{array}{l}\text { Eurheic Spring } \\
2017\end{array}$} \\
\hline & & $\mathrm{F}$ & $\mathrm{S}$ & IndVal & $\mathrm{F}$ & $\mathrm{S}$ & IndVal & $\mathrm{F}$ & $\mathrm{S}$ & IndVal & $\mathrm{F}$ & S & IndVal \\
\hline Achnanthidium eutrophilum (Lange-Bertalot) Lange-Bertalot & ADEU & 34 & 17 & 6 & 64 & 62 & 39 & 2 & 4 & 0 & 0 & 0 & 0 \\
\hline Cocconeis placentula Ehrenberg & CPLA & 0 & 0 & 0 & 93 & 19 & 18 & 7 & 4 & 0 & 0 & 0 & 0 \\
\hline Craticula cuspidata (Kützing) D.G.Mann & CRCU & 80 & 22 & 18 & 20 & 10 & 2 & 0 & 0 & 0 & 0 & 0 & 0 \\
\hline Denticula subtilis Grunow & DSUB & 0 & 0 & 0 & 21 & 5 & 1 & 79 & 17 & 14 & 0 & 0 & 0 \\
\hline Encyonema minutiforme Krammer & ENMF & 35 & 11 & 4 & 0 & 0 & 0 & 55 & 30 & 17 & 10 & 6 & 1 \\
\hline Eolimna minima (Grunow) Lange-Bertalot & EOMI & 10 & 39 & 4 & 59 & 57 & 34 & 24 & 48 & 11 & 7 & 22 & 2 \\
\hline Epithemia turgida (Ehrenberg) Kützing & ETUR & 21 & 33 & 7 & 69 & 43 & 30 & 3 & 13 & 0 & 6 & 11 & 1 \\
\hline Eunotia implicata Nörpel, Lange-Bertalot \& Alles & EIMP & 0 & 0 & 0 & 0 & 0 & 0 & 87 & 22 & 19 & 13 & 6 & 1 \\
\hline Eunotia minor (Kützing) Grunow & EMIN & 0 & 0 & 0 & 4 & 5 & 0 & 80 & 26 & 21 & 16 & 17 & 3 \\
\hline Eunotia pectinalis (Kützing) Rabenhorst & EPEC & 4 & 6 & 0 & 0 & 0 & 0 & 71 & 26 & 18 & 26 & 22 & 6 \\
\hline Fallacia pygmaea (Kützing) Stickle \& D.G.Mann & FPYG & 57 & 33 & 19 & 31 & 14 & 4 & 5 & 4 & 0 & 7 & 6 & 0 \\
\hline Fragilaria aff. capitellata (Grunow) J.B. Petersen & FCPLaff & 23 & 33 & 8 & 0 & 0 & 0 & 77 & 39 & 30 & 0 & 0 & 0 \\
\hline Fragilaria aff. pectinalis (O.F. Müller) Gray 1 & FPECaff & 2 & 6 & 3 & 0 & 0 & 1 & 0 & 0 & 3 & 98 & 33 & 2 \\
\hline Fragilaria aff. pectinalis (O.F. Müller) Gray 2 & FPECaff & 0 & 0 & 0 & 2 & 5 & 0 & 0 & 0 & 0 & 98 & 33 & 33 \\
\hline Gomphonema pumilum var. rigidum E.Reichardt \& Lange-Bertalot & GPRI & 20 & 39 & 8 & 7 & 19 & 1 & 15 & 39 & 6 & 59 & 56 & 33 \\
\hline Gomphonema truncatum Ehrenberg & GTRU & 5 & 11 & 1 & 17 & 19 & 3 & 17 & 26 & 5 & 61 & 39 & 24 \\
\hline Karayevia clevei (Grunow) Bukhtiyarova & KCLE & 9 & 22 & 2 & 82 & 52 & 43 & 7 & 26 & 2 & 1 & 6 & 0 \\
\hline Melosira varians C. Agardh & MVAR & 13 & 28 & 4 & 16 & 48 & 8 & 23 & 30 & 7 & 48 & 61 & 30 \\
\hline Navicula erifuga Lange-Bertalot & NERI & 76 & 22 & 17 & 16 & 10 & 2 & 8 & 4 & 0 & 0 & 0 & 0 \\
\hline Nitzschia amphibia Grunow & NAMP & 38 & 33 & 13 & 54 & 62 & 33 & 4 & 17 & 1 & 4 & 17 & 1 \\
\hline Nitzschia filiformis var. conferta (Richter) Lange-Bertalot & NFIC & 0 & 0 & 0 & 93 & 19 & 18 & 7 & 4 & 0 & 0 & 0 & 0 \\
\hline Nitzschia gracilis Hantzsch & NIGR & 16 & 11 & 2 & 0 & 0 & 0 & 30 & 22 & 7 & 54 & 33 & 18 \\
\hline Nitzschia intermedia Hantzsch ex Cleve \& Grunow & NINT & 62 & 39 & 24 & 10 & 19 & 2 & 12 & 17 & 2 & 15 & 22 & 3 \\
\hline Nitzschia supralitorea Lange-Bertalot & NZSU & 65 & 67 & 44 & 11 & 33 & 4 & 11 & 26 & 3 & 12 & 33 & 4 \\
\hline Nitzschia valdestriata Aleem \& Hustedt & NIVA & 6 & 11 & 1 & 73 & 48 & 35 & 21 & 22 & 5 & 0 & 0 & 0 \\
\hline Planothidium cf. frequentissimum (Lange-Bertalot) Lange-Bertalot & PLFRcf & 5 & 6 & 0 & 11 & 5 & 1 & 0 & 0 & 0 & 84 & 22 & 19 \\
\hline Planothidium pericavum (J.R. Carter) Lange-Bertalot & PPCV & 90 & 28 & 25 & 0 & 0 & 0 & 0 & 0 & 0 & 10 & 6 & 1 \\
\hline Pseudofallacia tenera (Hustedt) Liu, Kociolek \& Wang & PFTN & 42 & 33 & 14 & 54 & 38 & 21 & 0 & 0 & 0 & 3 & 6 & 0 \\
\hline Pseudostaurosira brevistriata (Grunow) D.M.Williams \& Round & PSBR & 7 & 17 & 1 & 92 & 38 & 35 & 2 & 4 & 0 & 0 & 0 & 0 \\
\hline Pseudostaurosiropsis sp.1 & PSRP & 24 & 28 & 7 & 75 & 38 & 28 & 1 & 4 & 0 & 0 & 0 & 0 \\
\hline Sellaphora pupula (Kützing) Mereschkowksy & SPUP & 52 & 56 & 29 & 34 & 52 & 18 & 10 & 17 & 2 & 4 & 11 & 0 \\
\hline Staurosirella pinnata (Ehrenberg) D.M.Williams \& Round & SPIN & 0 & 0 & 0 & 100 & 24 & 24 & 0 & 0 & 0 & 0 & 0 & 0 \\
\hline Surirella angusta Kützing & SANG & 73 & 44 & 32 & 5 & 10 & 0 & 15 & 30 & 5 & 7 & 28 & 2 \\
\hline Ulnaria acus (Kützing) Aboal & UACU & 6 & 11 & 1 & 1 & 5 & 0 & 40 & 35 & 14 & 53 & 61 & 33 \\
\hline
\end{tabular}


parameters), an Indicator Value analysis was performed to identify possible indicator species of each state (Table 2), except for the hyporheic (no differences were detected between this and the other states). This analysis showed that Craticula cuspidata (Kützing) D.G.Mann, Fallacia pygmaea (Kützing) Stickle \& D.G. Mann, Navicula erifuga Lange-Bertalot, Nitzschia intermedia Hantzsch ex Cleve \& Grunow, Nitzschia supralitorea Lange-Bertalot, Planothidium pericavum (J.R.Carter) Lange-Bertalot, Sellaphora pupula (Kützing) Mereschkowksy and Surirella angusta Kützing are characteristic of arheic condition (except during Summer 2017); Achnanthidium eutrophilum (Lange-Bertalot) Lange-Bertalot, Cocconeis placentula Ehrenberg, Eolimna minima (Grunow) Lange-Bertalot, Epithemia turgida (Ehrenberg) Kützing, Karayevia clevei (Grunow) Bukhtiyarova, Nitzschia amphibia Grunow, Nitzschia filiformis var. conferta (Richter) Lange-Bertalot, Nitzschia valdestriata Aleem \& Hustedt, Pseudofallacia tenera (Hustedt) Liu, Kociolek \& Wang, Pseudostaurosira brevistriata (Grunow) D.M.Williams \& Round, Pseudostaurosiropsis sp. 1 and Staurosirella pinnata (Ehrenberg) D.M.Williams \& Round are characteristic of arheic conditions during Summer 2017. In turn, Denticula subtilis Grunow, Encyonema minutiforme Krammer, Eunotia implicata Nörpel, Lange-Bertalot \& Alles, Eunotia minor (Kützing) Grunow, Eunotia pectinalis (Kützing) Rabenhorst, Fragilaria aff. capitellata (Grunow) J.B.Petersen and Nitzschia gracilis Hantzsch are characteristic of the eurheic condition. On the other hand, two Fragilaria species with affinity to the pectinalis group, Gomphonema pumilum var. rigidum E.Reichardt \& Lange-Bertalot, Gomphonema truncatum Ehrenberg, Melosira varians C.Agardh, Planothidium cf. frequentissimum (Lange-Bertalot) LangeBertalot and Ulnaria acus (Kützing) Aboal are characteristic of the eurheic conditions in Spring 2017. According to the ecological preferences of these aquatic states indicator species (retrieved from Van Dam et al., 1994 and Denys, 1991, in the OMNIDIA v. 5.5 database, compiled by Lecointe et al., 1993 and updated in 2011), no information was available for 8 taxa (Planothidium pericavum, Nitzschia filiformis var. conferta, Pseudofallacia tenera and Pseudostaurosiropsis sp. 1 for the arheic condition; and Denticula subtilis, Encyonema minutiforme and the two Fragilaria species with affinity to the pectinalis group).
3.3.5. Are diatoms in dry biofilm good ecological status indicators during the dry-phase?

To test this hypothesis, SPI values were converted to Ecological Quality Ratios (EQR). The EQRs ranged between 0.24 in the Winter pool in Palheta stream and 1.14 at Barranco de João Dias in Spring 2017, and the classification was mostly High, and Good, but some sites were classified as Moderate and Poor. In Fig. 11, the box-plots with the mean (given that $\mathrm{EQR}$ follows a normal distribution) by aquatic state, reveal that highest values were detected in eurheic conditions (both in Spring 2017 and in the other seasons), whilst arheic conditions in Winter 2017/ 2018 and Spring 2018 showed the worst ecological status. Significant differences were detected between aquatic states with $\mathrm{F}=3.739$, $p=0.008$, with the Holm-Sidak test separating ahreic conditions in Spring 2018 and Winter 2017/2018 from all aquatic states, except for arheic conditions in Summer 2017. The fact that no differences were detected between hyporheic and eurheic EQRs and the fact that lower EQRs (and consequently ecological status) in dry conditions were identified in sites that also presented low EQRs in eurheic conditions, led us to test the hypothesis that the EQRs determined for dry biofilm samples in Summer 2017 are comparable with the values from the previous Spring 2017 (in eurheic conditions, following standard sampling). The One-way ANOVA ( $\mathrm{F}=0.486, p=0.491)$ did not reveal differences between EQRs of samples collected in dry biofilm in Summer 2017 and the previous Spring 2017 sampling under flowing conditions, leading us to validate our hypothesis.

\subsubsection{Conservation status of benthic diatoms in Southern Portugal intermit- tent watercourses}

The analysis of the conservation status was carried out according to Lange-Bertalot and Steindorf (1996) and Hofmann et al. (2011), updated and available in the OMNIDIA database, since no detailed historical data are available for Portugal. This analysis revealed that 3 taxa are "in danger" (Diploneis parma Cleve, Halamphora oligotraphenta (LangeBertalot) Levkov and Amphora inariensis Krammer), 5 are under "some threat" (Navicula notha J.H.Wallace, Gomphonema tergestinum (Grunow) Fricke, Aulacoseira subarctica (O.Müller) E.Y.Haworth, Ulnaria biceps (Kützing) Compère and Eunotia implicata Nörpel, Lange-Bertalot \& Alles), 5 are "very rare" (Nitzschia valdecostata Lange-Bertalot \&

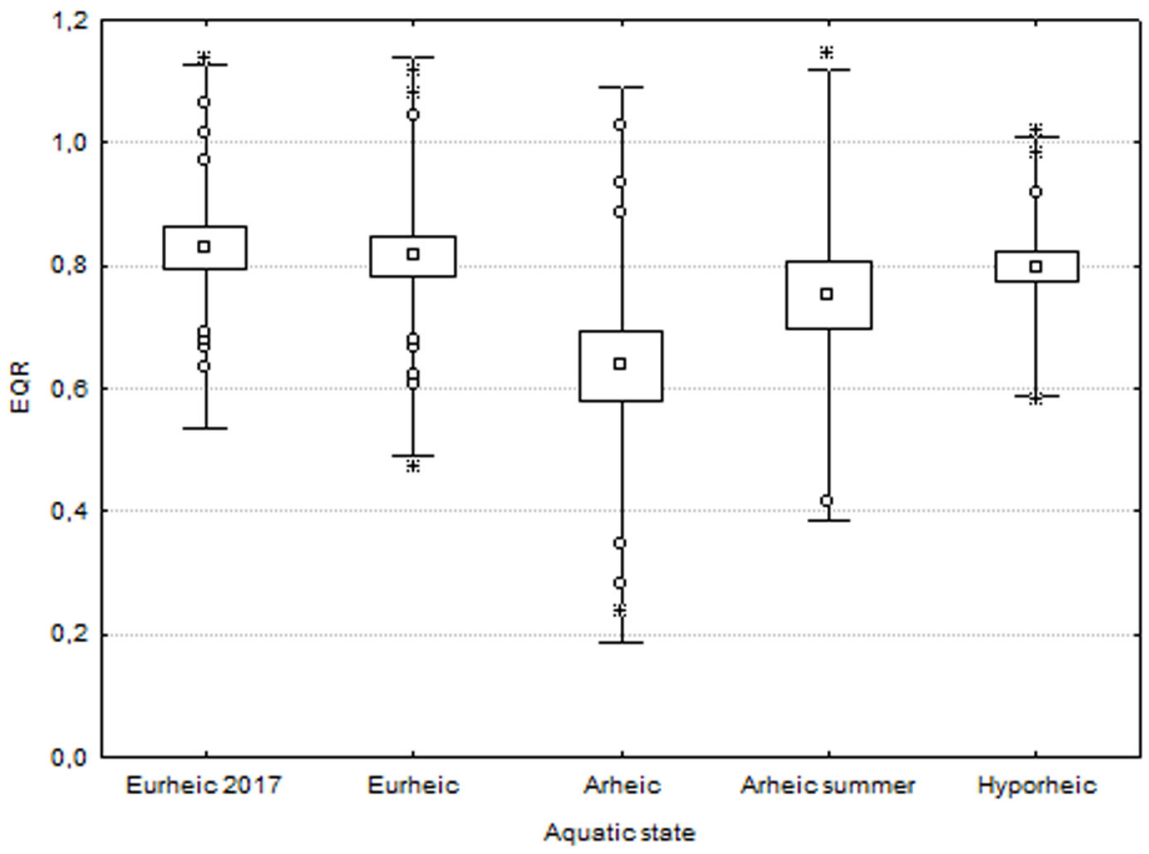

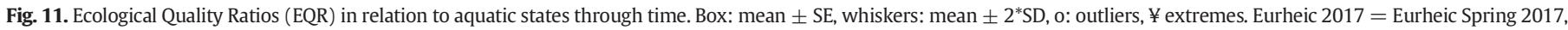

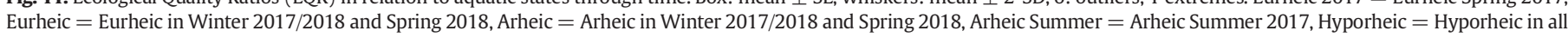
seasons. 
Simonsen, Nitzschia pumila Hustedt, Nitzschia pseudofonticola Hustedt, Navicula vandamii Schoeman \& Archibald and Gomphonema lagenula Kützing), 11 are "under regression" (Stauroneis anceps Ehrenberg, Neidium ampliatum (Ehrenberg) Krammer, Cocconeis neothumensis Krammer, Fragilaria tenera (W.Smith) Lange-Bertalot, Fragilaria nanana Lange-Bertalot, Gomphonema hebridense W.Gregory, Cymbella cymbiformis C.Agardh, Gomphonema exilissimum (Grunow) LangeBertalot \& E.Reichardt, Gomphonema lateripunctatum E.Reichardt \& Lange-Bertalot, Encyonema neomesianum Krammer and Eunotia pectinalis (Kützing) Rabenhorst), 3 are "widely distributed" and 60 are not threatened. For the remaining taxa, the risk was not estimated for 43 , insufficient information is available for 9 , and 49 of them are not listed. The three taxa "in danger" are present with maximum relative abundance of 3\% (Amphora inariensis) and 2\% (Diploneis parma and Halamphora oligotraphenta), Amphora inariensis and Halamphora oligotraphenta are only present in 2 samples (Amphora inariensis in pool samples and Halamphora oligotraphenta in flowing conditions); Diploneis parma, on the other hand, is present in 12 samples, with the highest abundance in Barranco de João Dias in Spring 2018, under flowing conditions. Among the 5 threatened taxa, Gomphonema tergestinum, Aulacoseira subarctica and Ulnaria biceps are abundant and frequent in the database, with maximum relative abundances of $26 \%$, $10 \%$ and $20 \%$, respectively, and they are present in 35,12 and 53 samples, respectively, whilst the two remaining (Navicula notha and Eunotia implicata) are present in low abundance and frequency. Gomphonema tergestinum is mainly present in samples collected in flowing conditions, with maximum in Safareja and Amieira streams. Aulacoseira subarctica is mainly identified in samples collected in dry biofilm and pools, with a maximum in Lampreia stream, and Ulnaria biceps is widely distributed in the dataset, with the maximum relative abundance detected in Malk Abraão stream in Spring 2017, under flowing conditions. The 5 taxa considered rare in central European rivers are also not very abundant in southern Portugal, with the maximum relative abundance of $6 \%$ detected for Nitzschia valdecostata, $4 \%$ for Nitzschia pumila, and only $2 \%$ for the remaining (Nitzschia pseudofonticola, Navicula vandamii, Gomphonema lagenula); these taxa are also not widely distributed, since Navicula vandamii is present in 12 samples (in flowing conditions, pool and dry biofilm, but with the highest abundance detected in Lampreia stream in the Winter pool), Nitzschia valdecostata in 7 samples (with the highest abundances detected in Summer samples, both under flowing conditions, in pool or dry biofilm, namely in Maria Delgada and Torgal Jusante streams and Barranco de João Dias), Gomphonema lagenula in 6 samples (highest abundances detected in Carvalho under flowing conditions in Winter 2017/2018 and Spring 2018, and in Barranco do Pelingroso in the Summer pool), Nitzschia pseudofonticola in 5 samples (with the highest relative abundance identified in Calastrão stream in dry biofilm) and Nitzschia pumila only in 3 samples (highest abundances detected under flowing conditions in Safareja stream and Barranco do Rio Seco, both in Spring 2018). Among the taxa considered "under regression", the majority is also present with low relative abundance in southern Portugal, except for Fragilaria tenera (34\% identified in Carvalho in Winter 2017/2018 under flowing conditions) and Fragilaria nanana (10\% in Cuncos stream in Spring 2017, under flowing conditions), and in few samples (maximum for Fragilaria tenera in 13, Gomphonema exilissimum in 11 and Eunotia pectinalis in 13 samples).

\section{Discussion}

The detected changes in water physicochemical parameters between aquatic states through time, highly controlled by flow intermittency and subsequent disruption of longitudinal connectivity are characteristic of intermittent rivers, as pointed out by Gómez et al. (2017). Mediterranean streams in southern Portugal usually resume flow in Autumn, with the first rains. Therefore, the occurrence of isolated pools in Winter reflects the low precipitation in 2017, since several rivers resumed flow only in Spring 2018, following the heavy rainfall events in March 2018 (visible in Fig. 3).

To explain the effect of wetting-drying cycle on key physicochemical parameters (e.g. DO, T, salinity, pH or TU), Gómez et al. (2017) pointed out several variables, namely, whether pools are formed after flow cessation, and variables concerning pool morphology (e.g. length, width, depth, orientation to the prevailing winds). Since no differences in pool morphology were detected, most probably the Winter and Spring pools analysed in this study were already subjected to some precipitation, resulting in the nutrient dilution, but not sufficient for flow resumption (see Fig. 3).

Diatom assemblages differed between aquatic regimes, with permanent streams clearly different from intermittent-pool and intermittentdry streams. The aquatic regime is the only factor common to these sites and this factor separated them from the others. These two permanent sites are far apart from each other, they belong to different WFD types and hydrographic basins, and they only share the absence of interruption in flow (see Table S1). Furthermore, they are under different meteorological conditions (see section 3.1) since Barranquinho is located in the southwest of the country, near the coast (see Fig. 3a with temperature and accumulated precipitation plot for the nearest meteorological station), under milder meteorological conditions, with relatively lower temperatures in Summer and relatively higher in Winter, and higher precipitations in 2018. Barranco de João Dias, on the other hand, is located in the east (see Fig. 3c), under harsher meteorological conditions in terms of temperature and the lower precipitation registered in 2018. Additionally, these two sites present typical hydromorphological characteristics of Mediterranean watercourses, such as the intermittentdry and intermittent-pool sites in the same region. Therefore, their aquatic regime is probably influenced by underground water, similarly to the cases reported by Novais et al. (2014).

The differences in diatom assemblages between seasons (only between Spring 2017 and Summer 2017) do not reflect the detected changes in water physicochemical parameters between the sampling seasons (as seen in the second axis of the PCA plot in Fig. 4), neither the meteorological conditions in the two years, as represented in the maps with temperature and precipitation (Figs. 1 and 2) and in the plots with the temporal evolution of temperature and accumulated precipitation (Fig. 3). Also the Portuguese Institute for Sea and Atmosphere (IPMA) classified the years differently, considering a severe drought since April 2017 until March 2018, whilst the year 2018 was classified as normal (IPMA, 2018).

The fact that diatom assemblages reflect changes in aquatic states through time presents implications for the ecological status assessment, since diatom assemblages differed between arheic conditions in Summer 2017 and other seasons. This issue was already raised by Gallart et al. (2012), who stated that even when pools are present, biotic communities are not representative of the ecological status of the stream, since conditions may vary among and within pools over time (even under reference conditions, which is the case in the present study).

The evaluation of diatom response to the hydrological disturbance through community analysis represents a challenge (Falasco et al., 2016a). However, in our study diatom assemblages reflect an intermittency gradient (through the succession of aquatic states through time, and the detected differences in the aquatic regime of sites), which is independent of the temporal scale since almost no differences were detected among sampling periods.

No differences were detected between aquatic regimes, aquatic states, sampling period or mesohabitat for species richness, whilst Shannon diversity and Pielou's Evenness indices reflected mesohabitat differences, with higher values for pools. These results are in opposition to Gallart et al. (2012), who state that when there are only pools in the reach, the biological communities may be significantly poorer in taxa or lower in diversity than the reference ones living in permanent streams. Also, Stubbington et al. (2017) state that in temperate zones, taxa richness may initially increase when the flow ceases and pools are formed, 
as lentic colonists join lotic refugees, later decreasing due to poor habitat suitability, declining water quality, and intense biotic interactions. Our results probably reflect an adaptation of benthic diatoms to Mediterranean intermittent streams, since pools were sampled at the end of the summer, several months after flow cessation.

As diatom indices were created to evaluate the response to organic load and nutrient concentrations, the negative correlations between SPI, nutrients, $\mathrm{pH}$ and EC would be expected (probably related to the increase in nutrient concentrations when the available water at the surface of the reach decreases). However, a negative correlation of SPI with the percentage of dry riverbed was also detected, revealing the index response to intermittency, contrary to the results of Falasco et al. (2016a), who found that functional metrics as chlorophyll $a$ were more reliable than diatom indices in drought impact assessments. It is widely recognized that the development of novel metrics to evaluate the ecological status of temporary streams is needed, since metrics developed for permanent streams may underestimate the ecological quality of temporary streams (Stubbington et al. (2017), since sensitivity to intermittence and to environmental degradation often covary. In our study, however, the SPI, developed for permanent streams presented a good response to changes in ecological quality, independent of the aquatic state (no differences were detected between aquatic states), even though mesohabitat and sampling period differences were detected, with lower SPI values in pools than under flowing water, and higher SPI values in Spring 2018 than in Summer 2017 and Winter 2017/2018.

The prevalence of the low-profile guild both in eurheic and arheic conditions (except in Summer) reflects their capacity to spread rapidly and their tolerance to physical disturbance, as detected by B-Béres et al. (2019) for Carpathian intermittent streams. Furthermore, as also referred by B-Béres et al. (2019), the low-profile dominance may also reflect the low nutrient concentrations during most of the study. The relative abundance of the high-profile guild did not change much through time, even though higher values were detected in eurheic conditions. The planktic guild was the less represented, with the lowest abundances detected in Summer arheic conditions. Their presence reflects the low water flow during the whole study (see Table S4) with no influence from reservoirs upstream of the selected sites. Similar results were detected by B-Béres et al. (2019) for permanent streams in the Carpathians. The motile taxa are linked to depositional habitats and increased siltation (Falasco et al., 2016a), therefore, their increase in abundance in arheic conditions was expected. It has also been reported for multihabitat sampling of Italian intermittent streams by Falasco et al. (2016a), who highlighted the importance of sampling lentic multihabitats, leading also to the inclusion of this part of the community that would otherwise remain underestimated, and which potentialities as physical disturbance indicators have already been recognized, namely the disturbance caused by seasonal flow variations (Lai et al., 2014; Falasco et al., 2016a).

The increase of species producing a mucilage pad in Summer, surpassing the mucilage stalk species in relative abundance was observed by Elias et al. (2015) in four Portuguese Atlantic-temperate streams. They showed that stalked species decreased immediately after a drought period. Therefore, we may hypothesize that a mucilage pad confers a better protection against dryness than the mucilage stalk, and further studies on the composition of the extracellular polymeric substances (EPS) could provide interesting insights into the physiological adaptation of benthic diatoms to dryness. Considering the life-forms, Piano et al. (2017b) found that motile, colonial and tube-forming ecological guilds are expected to favour species survival under intermittency conditions, also Elias et al. (2015) show a decrease in stalked diatom taxa immediately after drought.

With the lentification process, the decrease in low-profile taxa is visible, since these are taxa adapted to high current velocities and low nutrient conditions (Rimet and Bouchez, 2012). This process also favoured the increase of motile taxa, that occur under high nutrient concentrations but do not tolerate high current velocities (Rimet and Bouchez, 2012). This reflects the changes in nutrient concentrations caused by lentification, especially when Summer pools are formed (see Table S4, with the highest $\mathrm{TN}, \mathrm{NO}_{3}^{-}$and $\mathrm{PO}_{4}^{3-}$ concentrations were detected in arheic conditions in summer).

Most of the indicator species of the arheic state (both in Summer and during other seasons) range from circumneutral to alkaliphilous, are fresh brackish to brackish fresh (tolerating $\mathrm{Cl}^{-}$values from $<500$ to $1000 \mathrm{mg} \mathrm{L}^{-1}$ ). They are nitrogen-autotrophic, tolerating elevated concentrations of organically bound nitrogen or facultatively nitrogen-heterotrophic taxa, needing periodically elevated concentrations of organically bound nitrogen, requiring continuously high (3 taxa) to low (>30\% sat.) oxygen saturation. These same taxa range from oligosaprobous (only 1 taxon), alpha-meso/ polysaprobous (1 taxon), to beta- and alpha-mesosaprobous, are meso-eutraphentic to eutraphentic. They do not have clear moisture preferences, ranging from never occurring outside water bodies ( 3 taxa) to mainly occurring on wet and moist or temporarily dry places. As for the habitat and current requirements (following the classification of Denys 1991), most of them are also commonly found in periodic water or wet subaerial and commonly moist subaerial and indifferent in terms of current. These results are in accordance with Falasco et al. (2016a) and B-Béres et al. (2019), who state that under drought conditions there is an increase in aerophilous taxa, able to survive the drying up of the streams and rapidly colonize the habitats after water resumption.

The indicator species characteristic from the eurheic condition reveal the same preferences in terms of moisture, current and habitat. As for the $\mathrm{pH}$, several acidophilous taxa are also present, which agrees with the detected $\mathrm{pH}$ values (an increase in $\mathrm{pH}$ was observed together with a decrease in surface water, see Table S4). In terms of salinity, the range includes now some freshwater species $\left(<100 \mathrm{mg} \mathrm{L}^{-1} \mathrm{Cl}^{-}\right)$, and regarding the nitrogen uptake metabolism, some nitrogenautotrophic tolerating very small concentrations of organically-bound nitrogen are present, and only one needs periodically elevated concentrations of organically-bound nitrogen. Also the oxygen requirements are higher, with most species requiring continuously to fairly high oxygen saturation percentages ( $>75 \%$ sat.), which is also reflected in saprobity and trophic status (with the presence of oligosaprobous and mesotraphentic taxa).

The changes in indicator species following the aquatic state, with an increase in taxa tolerating elevated concentrations of organically bound nitrogen in arheic conditions, reflects the same pattern observed by Piano et al. (2017a), who stated that intermittency favours species with a wide ecological niche.

Our hypothesis that EQRs for dry biofilm samples in Summer were comparable with the previous Spring, was validated. Also Barthés et al. (2015) verified that the BDI diatom index was slightly affected by drying, but these effects had no significant influence on the ecological quality. This stability in the BDI index was related to the low index values, reflecting the dominance of tolerant species to nutrient enrichment. However, as it was suggested by Barthés et al. (2015), also in the present study this hypothesis was tested in sites under a wider range of anthropogenic influence, including several reference sites, validating the results and strongly suggesting the potential of diatoms in dry biofilm for the assessment of ecological quality during the dry-phase (see also Stubbington et al., 2019). Sampling of dry substrates is currently not required by standard protocols, but in the light of our results a modification of standard sampling methods (INAG, 2008; European Committee for Standardization, 2004), currently requiring the sampling of 5 pebbles, ought to be considered. A modification of the INAG method was used for the present study, collecting 10 pebbles along a $25 \mathrm{~m}$ transect in the middle of the channel, where evidence of previous presence of water was visible, to make sure sufficient material was collected. Clearly, as pointed out by Barthés et al. (2015), this 
proposed method should be further validated within the framework of other studies in order to propose the integration of dry biofilms in future monitoring programs. This in order to enhance biomonitoring and to contribute to an integral overview of river systems and to a better management of intermittent streams. This integrated ecological status evaluation, including the dry phase, is also important because, during this period, riverine ecosystems still harbour life and diatom communities are in part the seed for repopulation of the streams when the water flux resumes. This was verified after a short experiment of re-hydration of a dry biofilm sample that revealed viable cells (Novais, pers. observations). Furthermore, even though the suggested sampling method does not allow the distinction between live and dead diatoms, previous studies (e.g. Gillet et al., 2009) revealed that in small mountain streams, diatom assemblages generated from cell counts of live and dead diatoms were similar, their relationships with environmental variables were also similar and correlated well with in-stream physical habitat conditions.

Among the red list species of Southern Portugal, some taxa were also found in Mediterranean streams in Liguria (NW Italy) by Falasco et al. (2016b), namely Ulnaria biceps and Gomphonema tergestinum, which are the most abundant among the "probably endangered - G" group, and were found in samples collected in shallow and flowing waters (ca. $0.20 \mathrm{~m} / \mathrm{s}$ ). In southern Portugal, these species were mostly present in flowing waters, but reached higher abundances, contrary to the observations of Falasco et al. (2016b) and Bey and Ector (2013), confirming the role of Mediterranean streams in Southern Portugal as hot spots of biodiversity.

\section{Conclusions}

A temporal succession of aquatic states was detected through changes in diatom assemblages and the SPI index, reflecting both spatial (at a reach scale) and temporal gradients (the replacement of aquatic states through time), revealing also this biotic response to water availability. Furthermore, this intermittency response was also detected by changes in diatom assemblages and SPI between the aquatic regime of sites (permanent sites differ from intermittent-pool and intermittentdry). Clearly, the availability of surface water is more important in shaping diatom communities and indices than the temporal scale defined by the sampling periods. Also, functional metrics as the ecological guilds and life-forms reveal differences in aquatic states and habitat.

We showed that diatom assemblages collected in hard substrate under flowing water differed from those collected in pools and in dry biofilm. Also SPI, Shannon diversity and taxa richness reflected mesohabitat differences. Shannon diversity index and SPI from dry biofilm samples present intermediate values between samples collected in flowing and lentic conditions. Therefore, the conversion of SPI values into EQR did not reveal differences between dry biofilm samples collected in Summer 2017 and the previous Spring sampling under flowing conditions, leading to the validation of the hypothesis that benthic diatoms in dry biofilm are potential indicators of ecological status when there is no surface water in the reach.

The Mediterranean region is already known as a biodiversity hotspot, furthermore, intermittent rivers are also well recognized as highly diverse. This is a fact proved in this study with the analysis of the conservation status of the diatom flora present in the dataset, with 24 threatened taxa ( $6.06 \%$ of the total), namely: 3 taxa classified as "in danger", 5 under "some threaten", 5 "very rare" and 11 "under regression", revealing the importance of the implementation of adequate conservation and management measures of these river systems and their respective watersheds.

\section{Declaration of competing interest}

The authors declare that there are no conflicts of interest.

\section{Acknowledgements}

The work was funded by the European Union through the European Regional Development Fund, included in the COMPETE 2020 (Operational Program Competitiveness and Internationalization) through the ALOP (ALT20-03-0145-FEDER-000004) project and the ICT project (UIDB/04683/2020) with the reference POCI-01-0145-FEDER 007690, and by the Science and Management of Intermittent Rivers \& Ephemeral Streams (SMIRES) COST Action (CA15113), http://www.smires.eu/. We thank Josué Figueira for the valuable help with field work, Ana Pedro for the River Habitat Survey characterization and Anabela Rosado and Inês Mavioso for the water chemistry analysis. We also acknowledge the Portuguese Institute for Sea and Atmosphere (IPMA) for providing meteorological data and the Agência Portuguesa do Ambiente I.P./ Administração da Região Hidrográfica do Alentejo (ARH Alentejo) for the estimations on the percentage of the river network with intermittent regime.

\section{Appendix A. Supplementary data}

Supplementary data to this article can be found online at https://doi. org/10.1016/j.scitotenv.2020.137462.

\section{References}

Acuña, V., Datry, T., Marshall, J., Barceló, D., Dahm, C.N., Ginebreda, A., McGregor, G., Sabater, S., Tockner, K., Palmer, M.A., 2014. Why should we care about temporary waterways? Science 343, 1080-1081. http://palmerlab.umd.edu/pubs/acuna_etal_2014. pdf.

AFNOR, 2003. Norme française NF EN 13946. Qualité de l'eau - Guide pour l'échantillonnage en routine et le prétraitement des diatomées benthiques de rivières. Association Française de Normalisation, France (18 pp).

Agência Portuguesa do Ambiente, 2016. Plano de gestão de região hidrográfica 2016/ 2021. Parte 2. Caracterização e diagnóstico, Anexo IV (36 pp).

APHA, 1995. Standard Methods for the Examination of Water and Wastewater. nineteenth ed. American Public Health Association, American Water Works Association, and Water Pollution Control Federation, Washington, D.C.

Barthés, A., Leflaive, J., Coulon, S., Peres, F., Rols, J.-L., Ten-Hage, L., 2015. Impact of drought on diatom communities and the consequences for the use of diatom index values in the river Maureillas (Pyrénées-Orientales, France). River Res. Appl. 31, 993-1002.

B-Béres, V., Tóthmérész, B., Bácsi, I., Borics, G., Abonyi, A., Tapolczai, K., Rimet, F., Bouchez, A., Várbíró, G., Török, P., 2019. Autumn drought drives functional diversity of benthic diatom assemblages of continental intermittent streams. Adv. Water Resour. 126, 129-136. https://doi.org/10.1016/j.advwatres.2019.02.010.

Berthon, V., Bouchez, A., Rimet, F., 2011. Using diatom life-forms and ecological guilds to assess organic pollution and trophic level in rivers: a case study of rivers in southeastern France. Hydrobiologia 673, 259-271. https://doi.org/10.1007/s10750-0110786-1.

Bey, M.Y., Ector, L., 2013. Atlas des diatomées des cours d'eau de la region Rhône-Alpes. Tome 1-6. Direction régionale de l'Environnement, de l'Aménagegement et du Logement Rhône-Alpes, France (1182 pp).

Blanco, S., Cejudo-Figueiras, C., Álvarez-Blanco, I., Bécare, E., Hoffmann, L., Ector, L., 2010. Atlas de las diatomeas de la cuenca del Duero/Diatom Atlas of the Duero Basin. Área de Publicaciones, Universidad de León, Spain (386 pp).

Boix, D., García-Berthou, E., Gascón, S., Benejam, L., Tornés, E., Sala, J., Benito, J., Munné, A., Solà, C., Sabater, S., 2010. Response of community structure to sustained drought in Mediterranean rivers. J. Hydrol. 383, 135-146. https://doi.org/10.1016/j. jhydrol.2010.01.014.

Chiu, M.-C., Leigh, C., Mazor, R., Cid, N., Resh, V., 2017. Anthropogenic threats to intermittent rivers and ephemeral streams. In: Datry, T., Bonada, N., Boulton, A.J. (Eds.), Intermittent Rivers and Ephemeral Streams: Ecology and Management. Elsevier, Amsterdam, the Netherlands, pp. 433-454. https://doi.org/10.1016/B978-0-12803835-2.00016-4.

Clarke, K.R., Ainsworth, M.A., 1993. Method of linking multivariate community structure to environmental variables. Mar. Ecol. Prog. Ser. 92, 205-219.

Clarke, K.R., Gorley, R.N., 2001. PRIMER. PRIMER-E Ltd, Plymouth, UK.

COST Action 719 Final Report, 2008. In: Tveito, O.E., Wegehenkel, M., van der Wel, F. Dobesch, H. (Eds.), The use of geographic information systems in climatology and meteorology. Office for Official Publications of the European Communities, Luxembourg.

Coste, M., 1982. Etude des Méthodes Biologiques Quantitatives d'Appréciation de la Qualité des Eaux. Cemagref. Agence de l'Eau Rhône-Méditerranée-Corse, PierreBénite., Lyon, France.

Datry, T., Fritz, K., Leigh, C., 2016. Challenges, developments and perspectives in intermittent river ecology. Freshw. Biol. 61, 1171-1180. https://doi.org/10.1111/fwb.12789.

Delgado, C., Pardo, I., García, L., 2012. Diatom communities as indicators of ecological status in Mediterranean temporary streams (Balearic Islands, Spain). Ecol. Indic. 15, 131-139. https://doi.org/10.1016/j.ecolind.2011.09.037. 
Delgado, C., Novais, M.H., Blanco, S., Almeida, S.F.P., 2015. Examination and comparison of Fragilaria candidagilae sp. nov. with type material of Fragilaria recapitellata, F. capucina, F. perminuta, F. intermedia and F. neointermedia (Fragilariales, Bacillariophyceae). Phytotaxa 231, 1-18. https://doi.org/10.11646/phytotaxa.231.1.1.

Delgado, C., Novais, M.H., Blanco, S., Almeida, S.F.P., 2016. Fragilaria rinoi sp. nov. (Fragilariales, Fragilariophyceae) from periphytic river samples in Central Portugal. Eur. J. Taxon. (248), 1-16 https://doi.org/10.5852/ejt.2016.248.

Denys, L., 1991. A check-list of the diatoms in the Holocene deposits of the western Belgian coastal plain with a survey of their apparent ecological requirements. I. Introduction, ecological code and complete list. Geological Survey of Belgium, 1991/02 - 246.

Directive 2000/60/EC of the European Parliament and of the Council of 23 October 2000 Establishing a framework for community action in the field of water policy. Off. J. Eur. Communities L327, 1-72.

Dufrêne, M., Legendre, P., 1997. Species assemblages and indicator species: the need for a flexible asymmetrical approach. Ecol. Monogr. 67, 345-366. https://doi.org/10.1890/ 0012-9615(1997)067[0345:SAAIST]2.0.CO;2.

Elias, C.L., Calapez, A.R., Almeida, S.F.P., Feio, M.J., 2015. From perennial to temporary streams: an extreme drought as a driving force of freshwater communities' traits. Mar. Freshw. Res. 66, 469-480. https://doi.org/10.1071/MF13312.

Environment Agency, 2003. River habitat survey in Britain and Ireland. Field Survey Guidance Manual, Bristol, England.

European Committee for Standardization, 2003. Water quality: guidance for routine sampling of benthic algae in shallow swift running waters. Comité Europeén de Normalisation, CEN TC230 N68. Brussels, Belgium (14 pp).

European Committee for Standardization, 2004. The European Standard. Water quality. Guidance standard for the identification, enumeration and interpretation of benthic diatom samples from running waters. Comité Europeén de Normalisation, CEN/TC 230. EN 14407. Brussels, Belgium (12 pp).

Falasco, E., Piano, E., Bona, F., 2016a. Suggestions for diatom-based monitoring in intermittent rivers. Knowl. Manag. Aquat. Ecosyst. 417, 38. https://doi.org/10.1051/ $\mathrm{kmae} / 2016025$.

Falasco, E., Piano, E., Bona, F., 2016b. Diatom flora in Mediterranean streams: flow intermittency threatens endangered species. Biodivers. Conserv. 25, 2965-2986. https:// doi.org/10.1007/s10531-016-1213-8.

Gallart, F., Prat, N., García-Roger, E.M., Latron, J., Rieradevall, M., Llorens, P., Barberá, G.G., Brito, D., De Girolamo, A.M., Porto, A.L., Buffagni, A., 2012. A novel approach to analysing the regimes of temporary streams in relation to their controls on the composition and structure of aquatic biota. Hydrol. Earth Syst. Sci. 16, 3165-3182. https:// doi.org/10.5194/hess-16-3165-2012.

Gillet, N., Pan, Y., Parker, C., 2009. Should only live diatoms be used in the bioassessment of small mountain streams? Hydrobiologia 620, 135-147. https://doi.org/10.1007/ s10750-008-9624-5.

Giorgi, F., Lionello, P., 2008. Climate change projections for the Mediterranean region. Glob. Planet. Chang. 63, 90-104. https://doi.org/10.1016/j.gloplacha.2007.09.005.

Gómez, R., Arce, M.I., Baldwin, D.S., Dahm, C.N., 2017. Water physicochemistry in intermittent rivers and ephemeral streams. In: Datry, T., Bonada, N., Boulton, A.J. (Eds.), Intermittent Rivers and Ephemeral Streams: Ecology and Management. Elsevier, Amsterdam, The Netherlands, pp. 109-134. https://doi.org/10.1016/B978-0-12803835-2.00016-4.

Goodall, D.W., 1954. Objective methods for the classification of vegetation. III. An essay in the use of factor analysis. Aust. J. Bot. 2, 304-324

Hofmann, G., Werum, M., Lange-Bertalot, H., 2011. Diatomeen im Süßwasser-Benthos von Mitteleuropa. Bestimmungsflora Kieselalgen für die ökologische Praxis. Über 700 der häufigsten Arten und ihre Ökologie. A.R.G. Gantner Verlag K.G., Rugell, Germany (908 pp).

INAG, I.P., 2008. Manual para a Avaliação Biológica da Qualidade da Agua em Sistemas Fluviais Segundo a Directiva-Quadro da Água - Protocolo de Amostragem e Análise para o Fitobentos - Diatomáceas. Ministério do Ambiente, do Ordenamento do Território e do Desenvolvimento Regional. Instituto da Água, I. P, Lisboa.

IPCC, 2018. Summary for policymakers. In: Masson-Delmotte, V., Zhai, P., Pörtner, H.-O., Roberts, D., Skea, J., Shukla, P.R., Pirani, A., Moufouma-Okia, W., Péan, C., Pidcock, R., Connors, S., Matthews, J.B.R., Chen, Y., Zhou, X., Gomis, M.I., Lonnoy, E., Maycock, T., Tignor, M., Waterfield, T. (Eds.), Global Warming of $1.5^{\circ} \mathrm{C}$. an IPCC Special Report on the Impacts of Global Warming of $1.5^{\circ} \mathrm{C}$ above Pre-Industrial Levels and Related Global Greenhouse Gas Emission Pathways, in the Context of Strengthening the Global Response to the Threat of Climate Change, Sustainable Development, and Efforts to Eradicate Poverty. World Meteorological Organization, Geneva, Switzerland (32 pp).

IPMA, 2018. Situação de Seca Meteorológica, Boletim Seca, Dezembro 2017, 2018. Instituto Português do Mar e da Atmosfera, IP [in Portuguese]. http://www.ipma.pt/ pt/publicacoes/.

Kahlert, M., Albert, R.-L., Anttila, E.-L., Bengtsson, R., Bigler, C., Eskola, T., Gälman, V., Gottschalk, S., Herlitz, E., Jarlman, A., Kasperoviciene, J., Kokociński, M., Luup, H., Miettinen, J., Paunksnyte, I., Piirsoo, K., Quintana, I., Raunio, J., Sandell, B., Simola, H., Sundberg, I., Vilbaste, S., Weckström, J., 2009. Harmonization is more important than experience - results of the first Nordic-Baltic diatom intercalibration exercise 2007 (stream monitoring). J. Appl. Phycol. 21, 471-482. https://doi.org/10.1007/ s10811-008-9394-5.

Krammer, K., Lange-Bertalot, H., 1986. Bacillariophyceae 1. Teil: Naviculaceae. In: Ettl, H., Gerloff, J., Heynig, H., Mollenhauer, D. (Eds.), Süsswasserflora von Mitteleuropa. Gustav Fischer Verlag, Stuttgart, pp. 1-876 2/1.

Krammer, K., Lange-Bertalot, H., 1988. Bacillariophyceae 2. Teil: Bacillariaceae, Epithemiaceae, Surirellaceae. In: Ettl, H., Gerloff, J., Heynig, H., Mollenhauer, D. (Eds.), Süsswasserflora von Mitteleuropa. Gustav Fischer Verlag, Stuttgart, pp. 1-596 2/2.
Krammer, K., Lange-Bertalot, H., 1991a. Bacillariophyceae 3. Teil: Centrales, Fragilariaceae, Eunotiaceae. In: Ettl, H., Gerloff, J., Heynig, H., Mollenhauer, D. (Eds.), Süsswasserflora von Mitteleuropa. 2/3. Gustav Fischer Verlag, Stuttgart, pp. 1-576.

Krammer, K., Lange-Bertalot, H., 1991b. Bacillariophyceae 4. Teil: Achnanthaceae. Kritische Ergänzungen zu Navicula (Lineolatae) und Gomphonema. Gesamtliteraturverzeichnis Teil 1-4. In: Ettl, H., Gerloff, J., Heynig, H., Mollenhauer D. (Eds.), Süsswasserflora von Mitteleuropa. 2/4. Gustav Fischer Verlag, Stuttgart, pp. 1-437.

Lai, G.G., Padedda, B.M., Virdis, T., Sechi, N., Lugliè, A., 2014. Benthic diatoms as indicators of biological quality and physical disturbance in Mediterranean watercourses: a case study of the Rio Mannu di Porto Torres basin, northwestern Sardinia, Italy. Diatom Res. 29, 11-26.

Lange-Bertalot, H., Steindorf, A., 1996. Rote Liste der limnischen Kieselalgen (Bacillariophyceae) Deutschlands. Schr. -R. f. Vegetationskde. 28 pp. 633-677.

Lecointe, C., Coste, M., Prygiel, J., 1993. "Omnidia”: software for taxonomy, calculation of diatom indices and inventories management. Hydrobiologia 269-270, 509-513. https://doi.org/10.1007/BF00028048.

Novais, M.H., Hlúbiková, D., Morais, M., Hoffmann, L., Ector, L., 2011. Morphology and ecology of Achnanthidium caravelense (Bacillariophyceae), a new species from Portuguese rivers. Algol. Stud. 136, 131-150. https://doi.org/10.1127/1864-1318/2011/ 0136-0131.

Novais, M.H., Morais, M., Rosado, J., Dias, L.S., Hoffmann, L., Ector, L., 2014. Diatoms of temporary and permanent watercourses in Southern Europe (Portugal). River Res. Appl 30, 1216-1232. https://doi.org/10.1002/rra.2818.

Novais, M.H., Jüttner, I., Van de Vijver, B., Morais, M.M., Hoffmann, L., Ector, L., 2015. Morphological variability within the Achnanthidium minutissimum species complex (Bacillariophyta): comparison between the type material of Achnanthes minutissima and related taxa, and new freshwater Achnanthidium species from Portugal Phytotaxa 224, 101-139. https://doi.org/10.11646/phytotaxa.224.2.1.

Novais, M.H., Almeida, S.F.P., Blanco, S., Delgado, C., 2019. Morphology and ecology of Fragilaria misarelensis sp. nov. (Bacillariophyta), a new diatom species from southwest of Europe. Phycologia 58, 128-144. https://doi.org/10.1080/ 00318884.2018.1524245.

Passy, S.I., 2007. Diatom ecological guilds display distinct and predictable behavior along nutrient and disturbance gradients in running waters. Aquat. Bot. 86, 171-178. https://doi.org/10.1016/j.aquabot.2006.09.018.

Piano, E., Falasco, E., Bona, F., 2017a. How does water scarcity affect spatial and temporal patterns of diatom community assemblages in Mediterranean streams? Freshw. Biol. 62, 1276-1287. https://doi.org/10.1111/fwb.12944.

Piano, E., Falasco, E., Bona, F., 2017b. Mediterranean rivers: consequences of water scarcity on benthic algal chlorophyll $a$ content. J. Limnol. 76, 39-48. https://doi.org/10.4081/ jlimnol.2016.1503.

Potes, M., Salgado, R., Costa, M.J., Morais, M., Bortoli, D., Kostadinov, I., Mammarella, I. 2017. Lake-atmosphere interactions at Alqueva reservoir: a case study in the summer of 2014. Tellus A: Dynamic Metereology and Oceanography 69 (1), 1272787 https://doi.org/10.1080/16000870.2016.1272787 (2017).

Prygiel, J., Carpentier, P., Almeida, S., Coste, M., Druart, J.-C., Ector, L., Guillard, D., Honoré, M.-A., Iserentant, R., Ledeganck, P., Lalanne-Cassou, C., Lesniak, C., Mercier, I., Moncaut, P., Nazart, M., Nouchet, N., Peres, F., Peeters, V., Rimet, F., Rumeau, A. Sabater, S., Straub, F., Torrisi, M., Tudesque, L., Van de Vijver, B., Vidal, H., Vizinet, J. Zydek, N., 2002. Determination of the biological diatom index (IBD NF T 90-354): results of an intercomparison exercise. J. Appl. Phycol. 14, 27-39. https://doi.org/ 10.1023/A:1015277207328.

R Core Team, 2019. R: A Language and Environment for Statistical Computing. R Foundation for Statistical Computing, Vienna, Austria http://www.R-project.org/.

Reichardt, E., 1997. Taxonomische revision des Artenkomplexes um Gomphonema pumilum (Bacillariophyceae). Nova Hedwigia 65, 99-130.

Rimet, F., Bouchez, A., 2012. Life-forms, cell-sizes and ecological guilds of diatoms in European rivers. Knowl. Manag. Aquat. Ecosyst. (406), 01 https://doi.org/10.1051/ kmae/2012018.

Robson, B.J., Matthews, T.G., Lind, P.R., Thomas, N.A., 2008. Pathways for algal recolonization in seasonally-flowing streams. Freshw. Biol. 53, 2385-2401. http://dro.deakin. edu.au/view/DU:30017320.

Sabater, S., Timoner, X., Bornette, G., De Wildes, M., Stromberg J.C., Stella, J.C. 2017. The biota of intermittent rivers and ephemeral streams: Algae and vascular plants. In Datry, T., Bonada, N., Boulton, A.J. (Eds.), Intermittent Rivers and Ephemeral Streams: Ecology and Management. Elsevier, Amsterdam, The Netherlands, pp. 189-216. https://doi.org/10.1016/B978-0-12-803835-2.00016-4.

Souffreau, C., Vanormelingen, P., Sabbe, K., Vyverman, W., 2013. Tolerance of resting cells of freshwater and terrestrial benthic diatoms to experimental desiccation and freezing is habitat-dependent. Phycologia 52, 246-255. https://doi.org/10.2216/12-087.1

StatSoft Inc, 2001. STATISTICA for Windows (Computer Program Manual). Tulsa, Oklahoma, U.S.A.

Stubbington, R., England, J., Wood, P.J., Sefton, C.E.M., 2017. Temporary streams in temperate zones: recognizing, monitoring and restoring transitional aquatic-terrestrial ecosystems. WIREs Water 4, e1223. https://doi.org/10.1002/wat2.1223.

Stubbington, R., Chadd, R., Cid, N., Csabai, Z., Miliša, M., Morais, M., Munné, A., Pařil, P., Pešić, V., Tziortzis, I., Verdonschot, R.C.M., Datry, T., 2018. Biomonitoring of intermittent rivers and ephemeral streams in Europe: current practice and priorities to enhance ecological status assessments. Sci. Total Environ. 618, 1096-1113. https://doi. org/10.1016/j.scitotenv.2017.09.137.

Stubbington, R., Paille, A., England, J., Barthès, A., Bouchez, A., Rimet, F., Sánchez-Montoya M.M., Westwood, C.G., Datry, T., 2019. A comparison of biotic groups as dry-phase indicators of ecological quality in intermittent rivers and ephemeral streams. Ecol. Indic. 97, 165-174. 
ter Braak, C.J.F., Šmilauer, P., 2002. CANOCO reference manual and CanoDraw for Windows user's guide. Software for Canonical Community Ordination (version 4.5). Biometris, Wageningen.

Tockner, K., Malard, F., Ward, J.V., 2000. An extension of the flood pulse concept. Hydrol. Process. 14, 2861-2883.

Tockner, K., Uehlinger, U., Robinson, C.T., 2009. Rivers of Europe. Academic Press, London, UK (728 pp).

Tooth, S., 2000. Process, form and change in dryland rivers: a review of recent research Earth Sci. Rev. 51, 67-107. https://doi.org/10.1016/S0012-8252(00)00014-3.
Van Dam, H., Mertens, A., Sinkeldam, J., 1994. A coded checklist and ecological indicator values of freshwater diatoms from The Netherlands. Neth. J. Aquatic Ecol. 28, 117-133. https://doi.org/10.1007/BF02334251.

Van de Vijver, B., Ector, L., Beltrami, M.E., de Haan, M., Falasco, E., Hlúbiková, D., Jarlman, A., Kelly, M., Novais, M.H., Wojtal, A.Z., 2011. A critical analysis of the type material of Achnanthidium lineare W. Sm. (Bacillariophyceae). Algol. Stud. 136/137, 167-192. https://doi.org/10.1127/1864-1318/2011/0136-0167.

Zelinka, M., Marvan, P., 1961. Zur Präzisierung der biologischen Klassifikation der Reinheit fliessender Gewässer. Arch. Hydrobiol. 57, 389-407. 